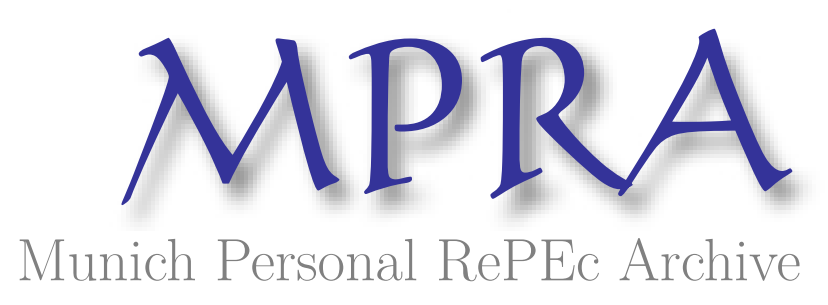

\title{
Variance Risk Premium Differentials and Foreign Exchange Returns
}

\author{
Arash, Aloosh \\ BI Norwegian Business School
}

30 November 2011

Online at https://mpra.ub.uni-muenchen.de/40829/

MPRA Paper No. 40829, posted 24 Aug 2012 11:21 UTC 


\title{
Variance Risk Premium Differentials and Foreign Exchange Returns
}

\author{
Arash Aloosh* \\ August 18, 2012
}

\begin{abstract}
The uncovered interest rate parity does not hold in the foreign exchange market (UIP puzzle). I use the cross-country variance risk premium differential to measure the excess foreign exchange return. Consequently, similar to Bansal and Shaliastovich (2010), I provide a risk-based explanation for the violation of UIP. The empirical results, based on the monthly data of ten currency pairs among US Dollar, UK Pound, Japanese Yen, Euro, and Swiss Franc, support the model both in-sample and out-of-sample.
\end{abstract}

Keywords: Consumption growth volatility-of-volatility; Variance risk premium differential; Global variance risk premium; Excess foreign exchange return; UIP.

\footnotetext{
*Department of Financial Economics at BI Norwegian Business School; arash.aloosh@bi.no; First draft: November 30, 2011. I gratefully thank Bruno Gerard for his invaluable supervision and many comments. I also thank Geert Bekaert, Geir Bjønnes, Christian Heyerdahl-Larsen, Salvatore Miglietta, Peter Nyberg (discussant at NFN workshop 2012), Richard Priestley, Piet Sercu (discussant at EFA Doctoral Tutorial 2012), Ivan Shaliastovich, Adrien Verdelhan and seminar participants at the BI brown bag and the BI PhD students meeting for their helpful comments and suggestions.
} 
According to the uncovered interest rate parity (UIP), when the foreign interest rate is higher than the domestic interest rate, the foreign currency should depreciate against the domestic currency by the difference between the two interest rates. However, except for very high inflation currencies, this does not hold in the data.

In this paper, I provide a risk based explanation for the UIP puzzle by using crosscountry variance risk premium differential. Several studies show that the consumption growth volatility is time-varying in the data; see Kandel and Stambaugh (1990) and Stock and Watson (2002). Bollerslev, Tauchen, and Zhou (2009) suggest that variance risk premium "effectively isolates the factor associated with the volatility of consumption growth volatility". As the ex ante realized consumption growth volatility changes in each period, we expect that investors (who care about total volatility) consider the distribution of consumption growth volatility or consumption growth volatility-of-volatility (or volatility risk), as in Bollerslev et al. (2009); see Figure 1.

Therefore, I argue that in response to a positive shock in domestic consumption growth volatility-of-volatility (domestic uncertainty) domestic investors demand higher expected excess return on foreign bonds (as they are more risk averse). In equilibrium, the price of foreign currency drops (foreign currency depreciates), consequently, they expect the foreign currency to appreciate tomorrow (higher expected return on investments abroad). At the same time, it pushes down the domestic interest rate. In other words, when the interest rate differential is high, they expect the foreign currency to appreciate against the domestic currency. This effect is similar to the finding of Bansal and Shaliastovich (2010). ${ }^{1}$

Bansal and Shaliastovich (2010) show that the expected excess foreign exchange return is a function of the consumption growth volatility differential. ${ }^{2}$ I extend the model of Bansal and Shaliastovich by using the general currency pricing model of Bekaert (1996) and the volatility-of-volatility model of Bollerslev et al. (2009), to show that the expected excess foreign exchange return is a function of both the consumption growth volatility differential and the consumption growth volatility-of-volatility differential.

Bekaert (1996), Backus et al. (2001) and many others use currency specific pricing kernels in the discrete time and provide a general currency pricing relation where the excess foreign exchange return is the half of the difference between variances of the loga-

\footnotetext{
${ }^{1}$ A positive shock to the domestic consumption growth volatility increases the variance of the logarithm of the domestic stochastic discount factor, and decreases the domestic price of foreign currency as in Bansal and Shaliastovich (2010). Similarly, a positive shock to the domestic consumption growth volatility-of-volatility increases the variance of the logarithm of the domestic stochastic discount factor, and decreases the domestic price of foreign currency immediately too. Colacito and Croce (2011) also study the cross-country-correlated long-run risk. However they assume constant risk premia and consequently cannot explain the UIP puzzle.

${ }^{2}$ Particularly, they show that when the cross-country consumption growth volatility differential increases, the equilibrium dollar price of foreign currency decreases.
} 
rithm of the stochastic discount factor in the local country and the foreign country. On the other hand, Bollerslev et al. (2009) allow for richer volatility dynamics than that is found in the original long-run risk model of Bansal and Yaron (2004). In particular, they allow for time-varying volatility-of-volatility of consumption growth, and show that the difference between the risk-neutral expected return variation and realized return variation (the variance risk premium) approximately measures the factor associated with the volatility of consumption growth volatility.

Theoretically, I derive the model-implied variance of the logarithm of the stochastic discount factor (SDF) of Bollerslev et al. (2009 and 2011). I find that the volatility of the logarithm of SDF has two components, the consumption growth volatility and the consumption growth volatility-of-volatility. Then, I substitute it in the model of Bekaert (1996). Moreover, consistent with the data, I assume that consumption growth volatility-of-volatilities and their components are not perfectly correlated across countries. Consequently, I find that the expected excess foreign exchange return is a function of both consumption growth volatility and consumption growth volatility-of-volatility components of SDF volatilities.

Besides Bansal and Shaliastovich (2010), several recent studies have some success in explaining the UIP puzzle, including Lustig and Verdelhan (2007), and Verdelhan (2010 and 2012). However, none of them tests their model in an out-of-sample horse race against the historical mean, as is Meese and Rogoff (1983 and 1988). ${ }^{3}$

Moreover, there is a growing literature studying the variance risk premia. For example, Bollerslev et al. (2009), and Drechsler and Yaron (2011) find a strong relation between the variance risk premia and the excess equity returns. Bollerslev et al. (2011) find that the global variance risk premia is even a better predictor of the excess aggregate equity returns than the domestic VRPs in each country. Also, Zhou (2010) and Mueller et al. (2011) find a strong tradeoff between the variance risk premia and the excess bond returns. To the best of my knowledge, this paper is first to study and document the tradeoff between variance risk premiums and excess foreign exchange returns.

Empirically, following Bollerslev et al. (2009), I estimate the variance risk premia (VRP) in the US, the UK, Japan, Europe, and Switzerland as a proxy for the consumption growth volatility-of-volatility in those countries. ${ }^{4}$ I calculate cross-country variance risk

\footnotetext{
${ }^{3}$ Since Meese and Rogoff (1983 and 1988), no model could predict individual exchange rate with a positive out-of-sample $R^{2}$ (in comparison with the historical mean). This was interpreted as no economic predictability of the exchange rate changes. The out-of-sample fit of my model is the first document in this literature.

${ }^{4}$ Following Britten-Jones and Neuberger (2000), Jiang and Tian (2005), and Bollerslev et al. (2009), Carr and Wu (2009), and Todorov (2010), I define the variance risk premia (VRP) as the difference between the risk-neutral and the actual (statistical) expectation of the future return variation. Bollerslev et al. (2009) show that VAR (beside the variance of consumption growth) explains a nontrivial fraction of aggregate stock market return. Moreover, Bollerslev et al. (2011) show that such VRP estimations
} 
premium differentials (DVRP), differences between VRPs in the domestic countries and the VRPs in the foreign countries (as a measure of cross-country consumption growth volatility-of-volatility differentials). Then, I show that spot exchange rates decrease when the variance risk premia differentials increase (see Figure 2). ${ }^{5}$

I investigate whether my findings are consistent with the currency common risk of Lustig et al. (2011), the global volatility of Menkhoff et al. (2012), and the global VRP of Bollerslev et al. (2011). I measure the global variance risk premium by the sum of market capital weighted variance risk premium in each country, as in Bollerslev et al. (2011). Then consistent with Lustig et al. (2011), Menkhoff et al. (2012), and Bollerslev et al. (2011), I find that there is a global factor in the foreign exchange market (the global VRP), and that is a good predictor of the excess foreign exchange returns and excess interbank rates (Libor) returns. Moreover, I separate the global VRP and country specific VRP, and I find that country-specific VRPs has some predictability power as well.

I show that the driving factors of variances of the logarithm of the SDFs are the same as those of the model-implied equity premium of Bollerslev et al. (2009). This provides an economically explanation for the contemporaneous comovements between the excess foreign exchange return and the cross-country excess equity return differential (the uncovered equity return parity) and the findings of Cappiello and De Santis (2005 and 2007) and Hau and Rey (2006). ${ }^{6}$

I also test whether VAR can predict the interbank rates; similar to Zhou (2010) and outside the US. I find that the global and country specific VRP are persistent predictor of excess one month holding of interbank rates with two month maturity both in the US and outside the US. Finally, I test the out-of-sample performance of my model against the historical mean.

The rest of the paper is organized as follows. Section 1 presents the two-country equilibrium model of volatility-of-volatilities. In section 2 , I describe the data and the empirical findings. Then, I provide the robustness checks in section 3. Section 4 concludes.

can persistently predict equity returns in France, Europe, Japan, Switzerland and UK, similar to what is previously documented for the US in Bollerslev et al. (2009). Furthermore, Zhou (2010) finds that variance risk premium also predicts excess bond return and credit spread in the US.

${ }^{5}$ This suggests that the excess foreign exchange return is a function of the cross-country consumption growth volatility-of-volatilities differential as well.

${ }^{6}$ Menkhoff et al. (2012) try to explain the uncovered equity return parity with their global FX volatility model. However, Backus et al. (2001) suggest an interpretation for the weakness of GARCH$\mathrm{M}$ models, which model the risk premium as a function of the conditional variance of the depreciation rate. The global FX volatility model of Menkhoff et al. (2012) has the same weakness. 


\section{A Two-Country Equilibrium Model with Volatility-of-Volatility}

In this section, I combine the general pricing model of Bekaert (1996) and the variance risk premium model of Bollerslev et al. (2009). I use an approach similar to the one used by Bollerslev et al. (2009) for equity markets to link the excess foreign exchange return to the variance risk premium differential.

Following Cochrane (2005), the logarithm of the risk-free rate, $r f_{t}$, can be written as: ${ }^{7}$

$$
\begin{aligned}
& r f_{t}=-\ln E\left[M_{t+1}\right]=-E\left[m_{t+1}\right]-\frac{1}{2} \operatorname{var}\left[m_{t+1}\right] \\
& \Rightarrow E\left[m_{t+1}\right]+r f_{t}=-\frac{1}{2} \operatorname{var}\left[m_{t+1}\right]
\end{aligned}
$$

where, $M_{t+1}$, is the stochastic discount factor, and $m_{t+1}\left(\equiv \log M_{t+1}\right)$ is the logarithm of the stochastic discount factor.

According to Bekaert (1996) among many others, the logarithm of the exchange rate change is equal to the difference between the logarithms of the stochastic discount factors in the two countries with frictionless markets,

$$
s_{t+1}-s_{t}=m_{t+1}^{*}-m_{t+1}
$$

where, $m_{t+1}^{*}$, is the logarithm of the stochastic discount factor in the foreign country (hereafter, all superscripts $*$ represent related variables in the foreign country), and $s_{t}$ is domestic spot price of one unit of foreign currency. ${ }^{8}$ Moreover, this relation shows that when the logarithm of the domestic stochastic discount factor increases, the spot exchange rate decreases (the foreign currency depreciates).

A one-period excess foreign exchange return is given by:

$$
r x_{t}^{f x}=s_{t+1}-s_{t}-r f_{t}+r f_{t}^{*}
$$

Bekaert (1996) among many others shows that taking expectations of both sides of

${ }^{7}$ The calculation is based on the following relation:

$$
E[\exp (x)]=\exp \left(E[x]+\frac{1}{2} \operatorname{var}[x]\right) \rightarrow \ln E[\exp (x)]=E[x]+\frac{1}{2} \operatorname{var}[x]
$$

${ }^{8}$ The variance of spot rate changes is $\operatorname{var}\left[s_{t+1}-s_{t}\right]=\operatorname{var}\left[m_{t+1}^{*}-m_{t+1}\right]$, therefore:

$$
\operatorname{var}\left[s_{t+1}-s_{t}\right]=\operatorname{var}\left[m_{t+1}^{*}\right]+\operatorname{var}\left[m_{t+1}\right]-2 \operatorname{cov}\left[m_{t+1}^{*}, m_{t+1}\right]
$$


the above equation, and replacing $E\left[m_{t+1}\right]+r f_{t}$ with $-\frac{1}{2} \operatorname{var}\left[m_{t+1}\right]$, we get:

$$
\begin{gathered}
E\left[r x_{t}^{f x}\right]=E\left[s_{t+1}-s_{t}-r f_{t}+r f_{t}^{*}\right] \\
E\left[r x_{t}^{f x}\right]=E\left[m_{t+1}^{*}-m_{t+1}-r f_{t}+r f_{t}^{*}\right] \\
E\left[r x_{t}^{f x}\right]=\frac{1}{2} \operatorname{var}\left[m_{t+1}\right]-\frac{1}{2} \operatorname{var}\left[m_{t+1}^{*}\right] .
\end{gathered}
$$

The expected excess foreign exchange return is a function of the difference of the variance of the logarithm of the stochastic discount factors in two countries, $f\left(\operatorname{var}\left[m_{t+1}\right]-\right.$ $\left.\operatorname{var}\left[m_{t+1}^{*}\right]\right) .{ }^{9}$ Therefore, a shock that increases (decreases) the variance of logarithm of stochastic discount factor in the domestic (foreign) country, will increase the expected excess foreign exchange return.

Bansal and Shaliastovich (2010) provide a long-run consumption-risk explanation for this relation. They argue that when domestic consumption growth volatility (or variance of logarithm of stochastic discount factor) increases, the domestic stochastic discount factor decreases, therefore the equilibrium domestic price of foreign currency drops immediately (or the foreign currency depreciates), which is consistent with equation 1. Relative to the new equilibrium price today, we expect the foreign currency to appreciate tomorrow. Hence our expected excess foreign exchange return increases, which is consistent with Cochrane (2011).

Next, I use the consumption growth volatility-of-volatility model of Bollerslev et al. (2009) to calculate the implied-variance of logarithm of stochastic discount factor.

Bollerslev et al. (2009) assume that the geometric growth rate of consumption, $g_{t+1}=\log \left(c_{t+1} / c_{t}\right)$, and the consumption growth volatility, $\sigma_{g, t+1}$, have the following joint process:

$$
\begin{gathered}
g_{t+1}=\mu_{g}+\sigma_{g, t} z_{g, t+1}, \\
\sigma_{g, t+1}^{2}=a_{\sigma}+\rho_{\sigma} \sigma_{g, t}^{2}+\sqrt{q_{t}} z_{\sigma, t+1}, \\
q_{t+1}=a_{q}+\rho_{q} q_{t}+\varphi_{q} \sqrt{q_{t}} z_{q, t+1},
\end{gathered}
$$

where $\mu_{g}>0$ represents the constant mean growth rate, $\sigma_{g, t}^{2}$, denotes time-varying variance in consumption growth with volatility-of-volatility in the consumption growth pro-

\footnotetext{
${ }^{9}$ In contrast, the variance of the spot rate changes is a function of sum of the variance of logarithm of stochastic discount factor in two countries, $g\left(\operatorname{var}\left[m_{t+1}^{*}\right]+\operatorname{var}\left[m_{t+1}\right]\right)$, see the previous footnote. Therefore, we cannot find a relation between expected excess foreign exchange return and the VRP in the exchange market using the variance of spot exchange rates. This may explain why Nicolin (2009) failed to find a relation between expected excess foreign exchange return and VRP in the exchange market using variance swaps of the spot exchange rates in currency options data. Backus et al. (2001) use a similar argument to explain the failure of GARCH-M models.
} 
cess, $q_{t}$. The parameters satisfy $a_{\sigma}>0, a_{q}>0,\left|\rho_{\sigma}\right|<1,\left|\rho_{q}\right|<1$, and $\varphi_{q}>0$; and $\left\{z_{g, t}\right\}$, $\left\{z_{\sigma, t}\right\},\left\{z_{q, t}\right\}$ are iid $\operatorname{Normal}(0,1)$ processes jointly independent with each other.

Moreover, they assume that the representative agent in the economy has Epstein-Zin-Weil recursive preferences. Therefore, the logarithm of the stochastic discount factor of the representative agent is:

$$
m_{t+1}=\theta \log (\delta)-\frac{\theta}{\psi} g_{t+1}+(\theta-1) r_{t+1}
$$

where, $\theta \equiv \frac{(1-\gamma)}{(1-1 / \psi)}, \delta$ denotes the subjective discount factor, $\psi$ equals the intertemporal elasticity of substitution, $\gamma$ refers to the coefficient of risk aversion, and $r_{t+1}$ is the time $\mathrm{t}$ to $\mathrm{t}+1$ return on the consumption asset which equals to:

$r_{t+1}=-\log \delta-\frac{\mu_{g}}{\psi}-\frac{(1-\gamma)^{2}}{(2 \theta)} \sigma_{g, t}^{2}+\left(\kappa_{1} \rho_{q}-1\right) A_{q} q_{t}+\sigma_{g, t} z_{g, t+1}+\kappa_{1} \sqrt{q_{t}}\left[A_{\sigma} z_{\sigma, t+1}+A_{q} \varphi_{q} z_{q, t+1}\right]$

This return statement is derived from a standard Campbell and Shiller (1988) loglinearization of return; $r_{t+1}=\kappa_{0}+\kappa_{1} p c_{t+1}-p c_{t}+g_{t+1}$, (for more detail, see Bollerslev et al. 2009).

The variance of the logarithm of the stochastic discount factor in this economy is then:

$$
\begin{gathered}
\operatorname{var}\left[m_{t+1}\right]=\operatorname{var}\left[\theta \log (\delta)-\frac{\theta}{\psi} g_{t+1}+(\theta-1) r_{t+1}\right] \\
\operatorname{var}\left[m_{t+1}\right]=\left(\frac{\theta}{\psi}\right)^{2} \operatorname{var}\left(g_{t+1}\right)+(\theta-1)^{2} \operatorname{var}\left(r_{t+1}\right)-2\left(\frac{\theta}{\psi}\right)(\theta-1) \operatorname{cov}\left(g_{t+1}, r_{t+1}\right) \\
\operatorname{var}\left[m_{t+1}\right]=\left(\frac{\theta}{\psi}\right)^{2} \sigma_{g, t}^{2}+(\theta-1)^{2}\left(\sigma_{g, t}^{2}+\kappa_{1}^{2}\left(A_{\sigma}^{2}+A_{q}{ }^{2} \varphi_{q}^{2}\right) q_{t}\right)-2\left(\frac{\theta}{\psi}\right)(\theta-1) \sigma_{g, t}^{2} \\
\operatorname{var}\left[m_{t+1}\right]=\left(\left(\frac{\theta}{\psi}\right)^{2}+(\theta-1)^{2}-2\left(\frac{\theta}{\psi}\right)(\theta-1)\right)\left[\sigma_{g, t}^{2}\right]+(\theta-1)^{2} \kappa_{1}{ }^{2}\left(A_{\sigma}{ }^{2}+A_{q}{ }^{2} \varphi_{q}{ }^{2}\right)\left[q_{t}\right] \\
\operatorname{var}\left[m_{t+1}\right]=\gamma^{2}\left[\sigma_{g, t}^{2}\right]+(\theta-1)^{2} \kappa_{1}{ }^{2}\left(A_{\sigma}{ }^{2}+A_{q}{ }^{2} \varphi_{q}{ }^{2}\right)\left[q_{t}\right]
\end{gathered}
$$

In this relation, the volatility of the logarithm of the stochastic discount factor has two components, the consumption growth volatility and the consumption growth volatility-ofvolatility. A positive shock to either of volatilities (the consumption growth volatility or the consumption growth volatility-of-volatility) increases the variances of the logarithm of the stochastic discount factor.

Bollerslev et al. (2009) suggest that we can use variance risk premia (VRP) as an 
estimate for the second term of expression 3;

$$
(\theta-1) \kappa_{1}\left(A_{\sigma}+A_{q} \kappa_{1}^{2}\left(A_{\sigma}^{2}+A_{q}^{2} \varphi_{q}^{2}\right) \varphi_{q}^{2}\right)\left[q_{t}\right] \simeq\left[V R P_{t}\right]
$$

so, we can write the variance of the logarithm of the SDF in equation 3 as a function of the consumption growth volatility and variance risk premia.

$$
\operatorname{var}\left[m_{t+1}\right]=\gamma^{2}\left[\sigma_{g, t}^{2}\right]+\lambda\left[V R P_{t}\right]
$$

where $\lambda=\frac{(\theta-1)^{2} \kappa_{1}^{2}\left(A_{\sigma}{ }^{2}+A_{q}{ }^{2} \varphi_{q}{ }^{2}\right)}{(\theta-1) \kappa_{1}\left(A_{\sigma}+A_{q} \kappa_{1}^{2}\left(A_{\sigma}{ }^{2}+A_{q}{ }^{2} \varphi_{q}{ }^{2}\right) \varphi_{q}{ }^{2}\right)}$. Finally, if we substitute equation (4) in equation (1), we get:

$$
\begin{aligned}
& E\left[r x_{t}^{f x}\right]=\frac{1}{2}\left\{\gamma^{2}\left[\sigma_{g, t}^{2}\right]+\lambda\left[V R P_{t}\right]\right\}-\frac{1}{2}\left\{\gamma^{* 2}\left[\sigma_{g, t}^{* 2}\right]+\lambda^{*}\left[V R P_{t}^{*}\right]\right\} \\
& E\left[r x_{t}^{f x}\right]=\frac{1}{2}\left\{\gamma^{2}\left[\sigma_{g, t}^{2}\right]-\gamma^{* 2}\left[\sigma_{g, t}^{* 2}\right]\right\}+\frac{1}{2}\left\{\lambda\left[V R P_{t}\right]-\lambda^{*}\left[V R P_{t}^{*}\right]\right\}
\end{aligned}
$$

This relation drives the specification of empirical tests conducted in this paper. Expression 5 says that the expected excess foreign exchange return has two components. The first component is a function of the consumption growth volatility differential, and the second component is a function of variance risk premia differential. By rearranging the equation 5 , we get:

$$
\begin{gathered}
E\left[r x_{t}^{f x}\right]=\frac{1}{2} \gamma^{2}\left\{\sigma_{g, t}^{2}-\sigma_{g, t}^{* 2}\right\}+\frac{1}{2}(\lambda)\left\{V R P_{t}-V R P_{t}^{*}\right\}+ \\
\frac{1}{2}\left(\gamma^{2}-\gamma^{* 2}\right)\left\{\sigma_{g, t}^{* 2}\right\}+\frac{1}{2}\left(\lambda-\lambda^{*}\right)\left\{V R P_{t}^{*}\right\} .
\end{gathered}
$$

We follow Bansal and Shaliastovich (2010), and assume that the subjective discount factors are equal across two countries $\left(\gamma=\gamma^{*}\right)$. If we assume that the coefficients of VRP are the same across two countries $\left(\lambda=\lambda^{*}\right)$, then, the expected excess foreign exchange return still has two components; the cross-country consumption growth volatility differential and the cross-country variance risk premium differential,

$$
E\left[r x_{t}^{f x}\right]=\frac{1}{2} \gamma^{2}\left\{\sigma_{g, t}^{2}-\sigma_{g, t}^{* 2}\right\}+\frac{1}{2}(\lambda)\left\{V R P_{t}-V R P_{t}^{*}\right\} .
$$

Equation 5 reduces to that of Bansal and Shaliastovich (2010), if and only if, the risk aversions are equal across two countries $\left(\gamma=\gamma^{*}\right)$ and variance risk premiums (or volatility-ofvolatilities) and their components are equal across two countries $\left(\lambda\left[V R P_{t}\right]=\lambda^{*}\left[V R P_{t}^{*}\right]\right)$ or consumption volatility is constant in both countries in which case, the VRP are zero in both countries $\left(V R P_{t}=V R P_{t}^{*}=0\right)$. In that case, the equation 5 reduces to the 
expected excess foreign exchange return of Bansal and Shaliastovich (2010),

$$
E\left[r x_{t}^{f x}\right]=\frac{1}{2} \gamma^{2}\left\{\sigma_{g, t}^{2}-\sigma_{g, t}^{* 2}\right\}
$$

According to this expression the excess foreign exchange return is a function of just the cross-country consumption growth variance differential. That means a positive shock to the domestic (foreign) consumption growth volatility increases (decreases) the variances of logarithm of the domestic stochastic discount factor. This leads to an increase (decrease) of the expected excess foreign exchange return. However, by relaxing their assumption of constant consumption (growth) volatility, and allowing consumption volatility to vary over time, the excess foreign exchange return is a function of the variance risk premium (consumption growth volatility-of-volatility) differential as well (see the equation 7 ). In this case, a positive shock to the domestic (foreign) variance risk premium increases the variances of the logarithm of the domestic (foreign) stochastic discount factor. This leads to an increase (decrease) of the expected excess foreign exchange return too.

Equation 7 is derived in a two-country setting (a bilateral world). In a multilateral world where the consumption depends on a global factor and country-specific factors (which are uncorrelated across countries), we can separate the global and the countryspecific components of both the consumption growth volatility and the variance risk premium. Then, we can express the expected excess foreign exchange return as a function of those global and country-specific components (as in the equation 8).

$$
\begin{gathered}
E\left[r x_{i j, t}^{f x}\right]=\frac{1}{2} \gamma^{2}\left(\tau_{g}^{i^{2}}-\tau_{g}^{j^{2}}\right)\left[\sigma_{g, t}^{g l^{2}}\right]+\frac{1}{2} \gamma^{2}\left[\sigma_{g, t}^{s i^{2}}-\sigma_{g, t}^{s j^{2}}\right] \\
+\frac{1}{2} \lambda^{g l}\left(\tau_{r}^{i^{2}}-\tau_{r}^{j^{2}}\right)\left[V R P_{t}^{g l}\right]+\frac{1}{2} \lambda^{s i}\left[V R P_{t}^{s i}-V R P_{t}^{s j}\right]
\end{gathered}
$$

In the above equation, $r x_{i j, t}^{f x}$ is the excess country i -country $\mathrm{j}$ exchange return, $\sigma_{g, t}^{g l}$ is the global consumption growth volatility, $\sigma_{g, t}^{s i}$ is country i-specific consumption growth volatility, $V R P_{t}^{g l}$ is the global VRP, and $V R P_{t}^{s i}$ is country i-specific VRP. ${ }^{10}$

In both the two country setting and the multilateral world, exchange rate returns are function of both consumption volatility and variance risk premium differentials across countries. Several studies find the consumption growth variance differential is not a strong predictor of excess equity or bond returns; see Hasseltoft (2012), Constantinides and Ghosh (2011), Beeler and Campbell (2009), and Lauterbach (1989). Bansal and Shaliastovich (2010) do not provide empirical evidence that the consumption growth variance differential predicts the excess foreign exchange return in the data either. In contrast, Bollerslev et al. (2009 and 2011) show that variance risk premia is a very good

\footnotetext{
10 See the Appendix A for a derivation of expression 8.
} 
predictor of excess equity return in the US and some developed countries, and Zhou (2010) and Mueller et al. (2011) find that the variance risk premia is a strong predictor of excess bond return in the US. In the next section, I test whether variance risk premia differential is a strong predictor of excess foreign exchange return.

\section{Data and Empirical Findings}

All of the data, except the consumption data, is from DataStream. The end-ofmonth MSCI spot exchange rate data for British Pound, Japanese Yen, Euro, and Swiss Franc against US dollars are available from the beginning of $1970 .{ }^{11}$ For the other spot exchange rates, for example Japanese Yen to British Pound (JPY/GBP), I divide the MSCI JPY/USD to the MSCI GBP/USD. One to six month inter-bank interest rates (Libor) in the countries are available from the beginning of 1986.

The daily aggregate market indices, S\&P 500 (US), FTSE 100 (UK), Nikkei 225 (Japan), STOXX (Europe), and SWX (Swiss) which are available from the beginning of 1978. The corresponding end-of-month model-free implied volatilities of S\&P 500 (from January 1990), FTSE 100 (from January 2000), Nikkei 225 (from January 1998), STOXX (from January 1999), and SWX (from January 1999). The monthly inflation (CPI) data from IMF International Financial Statistics (IFS) are mutually from January 1988 to May 2011.

I use retail sales data as a proxy for non-durable consumption, as in Lustig and Nieuwerburgh (2010), Ostergaard, Serensen, and Yosha (2002), Hass and Shin (2006 and 1998), Del Negro (2002 and 1998), and Wilcox (1989) among many others. That data (by country) is from OECD. The retail sales data in Europe is available since January 1995 (data for the other countries exists before this date).

\section{Summary statistics}

Tables 1 and 2 present the summary statistics of the data. The mean of interest and inflation rates are similar in the US and Europe, low (and even negative inflation) in Japan, and high in the UK. The variance risk premia (VRP) are similar in the US and UK with a monthly average of around 9 basis points and standard deviation of above 30 basis points and autocorrelation higher than $30 \%$. The variance risk premia has a large mean of 20.6 basis points in Europe, and a small mean of 3.8 basis points in Switzerland. The variance risk premia in Japan has the highest standard deviation of around monthly

\footnotetext{
11 Unfortunately, the implied-volatility of indices data is limited to S\&P 500 (US), FTSE 100 (UK), Nikkei 225 (Japan), STOXX (Europe), SWX (Swiss) and few other European countries (which their currency is euro). Therefore I am considering just these countries.
} 
38 basis points with a very small and negative autocorrelation of $-1 \%$.

Tables 3 provides the monthly correlations in all pairs of the currencies of the US, the UK, Japan, Europe, and Switzerland. The VRP in the UK is highly correlated with VRPs in the other countries with the highest monthly correlation of around $88 \%$ with that in the US. The VRPs in the Europe and Switzerland are highly correlated as well. The VRP in Japan has a lower correlation with VRPs in all other countries with the lowest monthly correlation of around $54 \%$ with that in the Europe. This supports our assumption that the VRPs are not perfectly correlated across countries. Interestingly, those pairs that their VRPs are more correlated, their VRP differential (DVRP) and excess exchange return (FX) are more correlated as well, For example US-UK VRP differentials and excess GBP/USD exchange returns are more than 33\% correlated.

\section{Variance Risk Premium Differential in the Data}

In order to test equation 7 , I use the following specification; ${ }^{12}$

$$
r x_{t}^{f x}=\alpha+\beta \times D I R_{t}+\gamma \times D V R P_{t}+\varepsilon_{t},
$$

where, $D I R$ is interest rate differential, and $D V R P_{t}\left(=V R P_{t}-V R P_{t}^{*}\right)$ is VRP differential. First, I just use traditional interest rate differentials to predict excess foreign exchange returns. Then I add variance risk premium differentials to the regression. The results are reports in the top and bottom panels of table 4 respectively.

The top panel of table 4 shows the relation between the interest rate differentials at time $t$ and the realized excess foreign exchange return at time $t+1$ for ten pairs of currencies on the period of January 2000 to October 2011. ${ }^{13}$ The Japan-US and Switzerland-Europe interest rate differentials are the only pairs that have statistically significant coefficients with low $R^{2}$.

The bottom panel of table 4 shows that adding the variance risk premium differential (DVRP) at time t to the regressions increases the $R^{2}$ in five pairs (GBP/USD, JPY/GBP, EUR/GBP, CHF/GBP, and CHF/EUR). The DVRP has significant correlation with the realized excess exchange return at time $t+1$ in two pairs; UK-US and Switzerland-Europe. The monthly US-UK DVRP can predict the monthly excess GBP/USD exchange returns in the period of January 2000 to October 2011. The US-UK DVRP coefficient has a correct sign (positive) with statistically significant Newey and West (1987) t-statistics of

\footnotetext{
${ }^{12}$ Consistent with VRP literature, the consumption growth volatility component is shot down.

${ }^{13}$ The data of the implied volatilities of indices starts at different times. Except that of S\&P 500 which starts on $01 / 1990$, the starting points of available data in the other countries vary from 01/1998 to $01 / 2000$. Therefore, in this paper, I test the data in the common periods from $01 / 2000$ to $09 / 2011$. The inferences are broadly unaffected when the regression s are estimated using all the data available for each currency pair.
} 
3.58 , and an adjusted $R^{2}$ of $10 \%$. Therefore, if the level of the monthly VRP in the US increases one percent relative to the monthly VRP in the UK (monthly US-UK DVRP increases by one percent) then we expect that the monthly excess GBP/USD exchange return increases more than 5.26 percent. Note that over this sample period, the US-UK interest rate differential has no predictive power.

Moreover, the monthly Europe-Sweitzerland DVRP can predict the monthly excess CHF/EUR exchange returns with statistically Newey and West t-statistics of -2.26 (incorrect negative sign), and an adjusted $R^{2}$ of about $8 \%$. The $R^{2}$ s for JPY/GBP, EUR/GBP, and $\mathrm{CHF} / \mathrm{GBP}$ have increased too (in the bottom panel of table 4). However their DVRP coefficients are not statistically significant.

These relations are consistent with the correlations in table 3. The correlation between DVRP and excess foreign exchange return (FX) is $33.6 \%$ in UK-US, around $29.6 \%$ in Switzerland-Europe. It is also high (but lower) in Switzerland-UK, Europe-UK, and Japan-UK.

However, according to table 3, the correlation between the FX return and domestic VRP (or foreign VRP) in some pairs of countries are even higher than the correlation between the DVRP and the FX return in those pairs. For example, the correlation between VRP in the US $\left(V R P_{U S}\right)$ and the GBP/USD FX return is $38.5 \%$ which is higher than the correlation between the US-UK VRP differential and the GBP/USD FX return, 33.6\%. Furthermore, monthly $V R P_{U S}$ and $V R P_{U K}$ are more than $87 \%$ correlated. There are similar relations in some other pairs of countries, e.g. the Japan-UK. If these correlations are related to a common risk factor in the foreign exchange market, as in Lustig et al. (2010 and 2011), then I am missing some information on comovements by looking just at the VRP differentials. If we assume that each currency has different exposure to a common factor (e.g. the global VRP), then, if two currencies have more exposure on the common factor, their VRPs will be more correlated. Those exposures to the common risk factor will affect their FX return, but they do not clearly show up in their DVRP regression in the bottom panel of table 4. Therefore, I check whether separating the common part of VRPs (the global VRP) from the country-specific VRPs can increase the predicting power.

\section{Global Variance Risk Premium in the Data}

Following, Bollerslev et al. (2011), I estimate the global VRP (or the common factor) as a value weighted average of the individual variance risk premia,

$$
G V R P_{t}=\sum_{i} \Omega^{i} V R P_{t}^{i}
$$


where, " $i$ refers to the US, UK, Japan, Europe, and Switzerland, and $\Omega^{i}$ is end-of-month market capitalization of country i from Datastream. Then, I divide VRP to country specific and global parts,

$$
V R P_{t}^{i}=V R P_{t}^{s, i}+\omega^{i} \times G V R P_{t}
$$

where $V R P_{t}^{i}$ is the observed VRP in country i, $V R P_{t}^{s i}$ is the country i-specific component, and $\omega^{i}$ is the country i's exposure to the global VRP, GVRP.

Consequently, the VRP differential is:

$$
\begin{gathered}
V R P_{t}-V R P_{t}^{*}=V R P_{t}^{s}+\omega \times G V R P_{t}-\left(V R P_{t}^{* s}+\omega^{*} \times G V R P_{t}\right) \\
V R P_{t}-V R P_{t}^{*}=\left(V R P_{t}^{s}-V R P_{t}^{* s}\right)+\left(\omega-\omega^{*}\right) \times G V R P_{t} \\
D V R P_{t}=D V R P_{t}^{s}+\left(\omega-\omega^{*}\right) \times G V R P_{t} .
\end{gathered}
$$

Equation 10 shows that VRP differential has two components; the country-specific component $\left(D V R P_{t}^{s}\right)$ and the common component $\left(\left(\omega-\omega^{*}\right) \times G V R P_{t}\right)$. If countries have the same exposure on the GVRP, then the common part equals zero and DVRP will be uncorrelated with GVRP. In addition, the more different exposure on the global component, the more correlation between DVRP and GVRP.

Since I assume that the global VRP and the country-specific VRP are uncorrelated, I can estimate the country-specific variance risk premia by using the following regression:

$$
V R P_{t}=\lambda+\rho \times G V R P_{t}+\zeta_{t}
$$

where, the country specific variance risk premium is the error term, $\left(V R P_{t}^{s}=\zeta_{t}\right)$. Then, I calculate the country specific VRP differentials and include them in the regressions. In order to estimate equation 7 , I use the following specification; ${ }^{14}$

$$
r x_{t}^{f x}=\alpha+\beta \times D I R_{t}+\gamma \times D V R P_{t}^{s}+\delta \times G V R P_{t}+\varepsilon_{t}
$$

where, $D V R P_{t}^{s}\left(=V R P_{t}^{s}-V R P_{t}^{* s}\right)$ is country specific VRP differential, and $G V R P_{t}$ is global VRP. The results of the estimation are reported in table 5 . It shows that the monthly global VRP and country specific VRP differentials significantly predict the monthly excess foreign exchange returns. The global VRP has statistically significant Newey and West t-statistics in five pairs (GBP/USD, JPY/USD, JPY/GBP, EUR/JPY, and CHF/JPY). The country specific VRP differentials are statistically significant in

\footnotetext{
${ }^{14}$ Consistent with the VRP literature, the consumption growth volatility component is shot down.
} 
three pairs (GBP/USD, EUR/GBP, and CHF/EUR). ${ }^{15}$

Moreover, separating the global VRP and country specific VRP differentials increases the adjusted $R^{2} \mathrm{~s}$ in all pairs except for CHF/EUR compared to the bottom panel of table 4. The highest adjusted $R^{2}$ is more than $16 \%$ and belongs to GBP/USD which its both components (the global and country specific component) are statistically significant. A positive coefficients of global VRP, $\delta_{G V R P}$, means that the domestic country has more exposure on the global VRP relative to the foreign country, e.g. US compared to UK, or Switzerland compared to Japan. A negative coefficients of $\delta_{G V R P}$, is less exposure of domestic country on the global VRP relative to the foreign country, e.g. US compared to Japan, or UK compared to Japan.

These findings are consistent with Lustig et al. (2010, 2011 and 2012) and Menkhoff et al. (2012). However, Lustig et al. (2010) and Menkhoff et al. (2012) use a basket of currencies, and my results are based on the pairs of currencies.

\section{Variance Risk Premium and Consumption Growth Volatility}

Equations 7 and 8 show that FX returns are function of both consumption growth volatility differentials and VRP differentials. In the VRP literature, authors shut down the consumption growth volatility component. The main reason is that the monthly consumption data is usually not available. In this section, I use retail sales data as a proxy for non-durable consumption. Then, following Bansal et al. (2005) and Bansal and Shaliastovich (2010), I construct consumption growth volatility measures as a 2-year sum of absolute residuals from $\mathrm{AR}(3)$ projections of monthly consumption (retail sale) growth rates. Finally, I add the estimated consumption growth volatility in my regression as in equation 7 .

Table 6 shows adding the estimated consumption growth volatility differentials into the regressions increases the adjusted $R^{2}$ in four pairs (JPY/GBP, EUR/GBP, CHF/GBP, and CHF/JPY) while it is statistically significant in one pair (JPY/GBP), compared to the results in the bottom panel of table 4 .

Moreover, I follow the same procedure as in the previous section to create global consumption growth volatility (GVOLC), country specific consumption growth volatilities $\left(V O L C^{s}\right)$, and country specific consumption growth volatility differentials $\left(D V O L C^{s}\right)$. Table 7 shows that substituting the estimated GVOLC and DVOLC ${ }^{s}$ (as in the regression 8 ) increases the adjusted $R^{2}$ in three pairs (JPY/USD, JPY/GBP, and CHF/GBP) while the coefficient of GVOLC is statistically significant in two pairs (JPY/USD and JPY/GBP), compared to the results in table 5.

\footnotetext{
15 the sign of coefficient of country specific VRP differentials are not correct for EUR/GBP and CHF/EUR
} 
Therefore, as the theoretical model suggests, the consumption growth volatility factors have some predictive power to explain monthly excess foreign exchange returns. But they are not empirically strong. This may explain why authors (in this literature) shut down the consumption growth volatility part. In the rest of the paper, I shut down the consumption growth volatility part as well.

\section{Robustness Tests}

\section{Contemporaneous Comovements in Equity and Exchange Markets}

Table 8 shows that the monthly cross-country excess equity return differential and the monthly excess foreign exchange return have highly significant contemporaneous comovements in most of the pairs, which have been previousely documented by Hau and Rey (2006) and Cappiello and De Santis (2005). I provide several explanation for their findings.

Bollerslev et al. (2009) show that their model-implied equity premium equals to:

$$
\pi_{r, t}=\gamma\left[{\sigma_{g, t}}^{2}\right]+(\theta-1) \kappa_{1}^{2}\left(A_{\sigma}^{2}+A_{q}^{2} \varphi_{q}^{2}\right)\left[q_{t}\right]
$$

where, $\pi_{r, t} \equiv-\operatorname{cov}_{t}\left(m_{t+1}, r_{t+1}\right)$.

This relation is very similar to equation 3 . In other words, the conditional variance of logarithm of stochastic discount factor and the expected excess equity return, in the model of Bollerslev et al. (2009), are driven by the same factors (the consumption growth volatility,$\sigma_{g, t}$, and the consumption growth volatility-of-volatility,$\left.q_{t}\right)$. The only difference is that the coefficients $\gamma$ and $(\theta-1)$ are squared in equation 3 and not for the equity premium. ${ }^{16}$ This suggests that we can use equity premium as an approximation of volatility of logarithm of SDF. Therefore, the cross-country excess equity return differential and the excess foreign exchange return should have contemporaneous comovements. This provides a risk-based explanation for the findings of Hau and Rey (2006) and Cappiello and De Santis (2005). ${ }^{17}$

Moreover, Bollerslev et al. (2011) show that VRP (and particularly the global VRP)

\footnotetext{
${ }^{16} \mathrm{~A}$ positive shock to the consumption growth volatility increases both the variance of the logarithm of the stochastic discount factor (or the expected excess foreign exchange return) and the expected excess equity return. Similarly, a positive shock to the consumption growth volatility-of-volatility increases both the variance of logarithm of stochastic discount factor (or expected excess foreign exchange return) and the expected excess equity return.

${ }^{17}$ The contemporaneous comovements between the cross-country excess equity return differential and the excess foreign exchange return is written in the following statement:
}

$$
r x_{t}^{f x}=\frac{1}{2} \operatorname{var}\left[m_{t+1}\right]-\frac{1}{2} \operatorname{var}\left[m_{t+1}^{*}\right] \simeq \frac{1}{2} \pi_{r, t}-\frac{1}{2} \pi_{r, t}^{*}
$$


in six major countries predict the individual country aggregate equity returns. If the risk premia across major financial markets commove, I investigate whether VRP differentials can predict equity premium differentials. The results are reported in table 9 . The table shows that the global VRP predicts just equity premium differentials between the US and other four countries. The UK-US country specific VRP differential is also the only significant predictor of FX returns among the currency pairs. ${ }^{18}$ ctually, the global VRP significantly predicts aggregate equity premium just in the US, and country specific VRPs significantly predict aggregate equity premium in the US and the UK in the sample period of January 2000 to October 2011 (these results are available on request). These results are slightly different from those of Bollerslev et al. (2011), for example, they find that the global VRP predicts aggregate equity premium in Germany and France. Instead, I use a Euro-wide aggregate equity index return, implied volatility, and realized volatility, and the global VRP cannot predict the Euro-wide aggregate equity premium. Moreover, Bollerslev's et al. (2011) sample period is slightly different (from January 2000 to December 2011).

\section{Inter-Bank Rates}

In this section, I test whether the VRPs can also predict the excess inter-bank returns in each country. The first reason is that the foundation of the relation between excess foreign exchange return and variance risk premium (in this paper) is based on the relation between variance risk premium (as a measure of aggregate uncertainty or aggregate risk aversion) and expected excess bond return (borrowing domestic bonds and investing in foreign bonds). Moreover, cross-country interest rates differentials are traditionally used as a predictor of excess foreign exchange return. If the interest rates (or inter-bank rates) are driven by the same factors, this supports that the previous success of interest rates differentials to predict excess foreign exchange returns may be due to the fact that they reflect similar factors.

First, I test whether the variance risk premia in the US, $V R P_{U S}$, can predict the excess US inter-bank return. The middle panel of table 9 shows that adding the $V R P_{U S}$ to the regression increases the adjusted $R^{2}$ to $27.40 \%$ (compared to the adjusted $R^{2}$ of $13.21 \%$ in the top panel), while the Newey-West t-statistics of the lagged forward spread coefficient remain statistically significant at 1 percent level. Therefore, the $V R P_{U S}$ has statistically significant power in forecasting the excess return of one month holding of a US Libor with two month to maturity. ${ }^{19}$ More interestingly, separating the global VRP and country specific VRP in the US significantly increases the adjusted $R^{2}$ while both

${ }^{19}$ These findings are similar to Zhou (2010) that the variance risk premia in the US predicts the excess US T-bill return.
} 
coefficients of global and country-specific VRP are statistically significant (see the bottom panel). This suggests that both the global and the country specific component of VRP in the US carry some information related to the excess return of holding interbank tares.

I repeat this test for the other countries. In the middle panel of table 10, I find that the coefficients of VRP in the UK and Japan are statistically significant (and the coefficient of VRP in Switzerland is marginally significant). ${ }^{20}$ To my best knowledge, this is the first document to show that the variance risk premia can forecast the excess bond return outside the US.

Then, I separate the global and country-specific components of VRP. Comparing the bottom and middle panels of table 10, we see that separating the global and countryspecific components increases $R^{2}$ in all countries. Moreover, both global and countryspecific components have statistically significant coefficients in the UK and US (particularly country specific VRP in the UK more significantly predicts the excess UK inter-bank return, compare to that in the US). This supports my other findings that the country specific US-UK VRP differential can predicts the excess GBP/USD exchange return. The global VRP has statistically significant coefficient in the Switzerland, and country-specific VRP has statistically significant coefficients in Japan. Both the global and countryspecific components of VRP have marginally significant coefficients in Europe. ${ }^{21}$

\section{Out-of-Sample}

Since Meese and Rogoff (1983 and 1988), spot exchange rates are known to be unpredictable out-of-Sample (OOS) particularly in comparison with a random walk with drift in monthly horizon, for example see Rogoff and Stavrakeva (2008) and Rogoff (2009) among many others. In this section, I test whether predicting the excess foreign exchange return based on the global VRP and country specific VRP differential also underperform predicting based on a random walk with drift (historical mean).

I evaluate the performance of my forecast based on the global VRP and country specific VRP differential using an OOS R-square similar to the one proposed by Goyal and Welch (2008). I use a 5-year training sample period from January 2000 to December 2004. The results are reported in table 11 and displayed in figure 3. The OOS R-squares is highly positive for GBP/USD. This means, in contrast to Meese and Rogoff (1983 and 1988), the excess GBP/USD exchange return (and spot exchange rates ) are better predicted by the global VRP and country specific VRP differential compared to the prediction by the historical mean. The $R_{O O S}^{2}$ of predicting monthly excess GBP/USD

\footnotetext{
${ }^{20}$ The coefficients of VRP in Japan has a positive sign which is in contrast with the theory (and the other countries).

${ }^{21}$ The coefficients of the country-specific VRP in all countries except US has a positive sign which is in contrast to the theory. The coefficient of global VRP in Japan is positive but not statistically significant.
} 
exchange return using the country specific VRP differential and the global VRP is $19.71 \%$ on the October 2011. The monthly $R_{O O S}^{2} \mathrm{~s}$ are positive except for JPY/USD, EUR/USD, and CHF/USD. These findings are consistent with my other findings that DVRP explains monthly excess GBP/USD exchange returns better than that of the other rates in-sample.

Moreover, Santa-Clara and Yan (2010), Bollerslev et al. (2009) and many other suggests that implied volatilities (and consequently VRP) can capture the ex ante crash risk assessed by investors (or some authors call it the higher risk aversion of investors) and therefore they are good predictors of the actual realized returns over horizon that the volatilities are higher. Therefore, as figure 3 shows for most currency pairs, a model including VRP differential does a better job at predicting FX returns OOS during the 2008 crises than the historical mean.

\section{Conclusion}

In this paper, I try to connect excess foreign exchange returns to cross-country variance risk premium differentials. Particularly, using Bekaert (1996) and Bollerslev's et al. (2009 and 2011), I show that the expected excess foreign exchange return is a function of the consumption growth volatility differential and the consumption growth volatilityof-volatility (measured by variance risk premium) differential between countries. This motivates the paper's empirical testable hypotheses.

The results show that cross-country VRP differentials have predictive power to explain excess foreign exchange returns. For example, one percent increase in the monthly variance risk premia in the US relative to the monthly variance risk premia in the UK (in the monthly US-UK variance risk premium differential) predicts 5.2 percents increase in the monthly excess British Pound/US Dollar exchange return (or around 5 percents appreciation in British Pound in next month) with statistically significant Newey-West t-statistics of 3.58 and adjusted $R^{2}$ of $10 \%$ in the period of January 2000 to October 2011.

Following Lustig et al. (2010) and Menkhoff et al. (2012), I separate the global component of the VRPs form the country-specific components. I find that both the global and country-specific component of VRP differentials help predict FX returns, although with varying importance across different currency pairs. Furthermore, including both global and country specific VRP differentials in the regression substantially improves the fit of the regression for most currency pairs.

Consistent with Zhou (2009), the monthly variance risk premia in the US can significantly predict the excess US interbank return. The monthly global and country specific VRP in the UK more significantly predict the excess UK interbank return with adjusted $R^{2}$ of $47 \%$, compared to that in the US. To my best knowledge, this is the first document that shows the variance risk premia can forecast the excess bond return outside 
the US. Moreover, the global VRP can significantly predict the excess bond return in the US, UK, Europe and Switzerland. This support the intuition suggested in this paper for explaining for the UIP puzzle. Also, it may explain previous success of interest rate differentials to predict FX returns.

Since in Bollerslev's et al. (2009), the model-implied variance of the logarithm of the stochastic discount factor and the model-implied expected equity premiums have the same driving factors, variation in these factors should drive contemporaneous comovements between the cross-country excess equity return differential and the excess foreign exchange return. This provides a risk-based explanation for the findings Hau and Rey (2006), and Cappiello and Santis (2005).

Finally, I find that using country-specific VRP differentials and the monthly global VRP to predict monthly foreign exchange returns substantially outperform the random walk model out-of-sample for most currency pairs. Particularly, country-specific US-UK VRP differential can predict the monthly GBP/USD exchange return with an out-ofsample $R^{2}$ of more than $19 \%$. This finding is in contrast with Meese and Rogoff (1983 and 1988). 


\section{References}

[1] Andrews, D. W. K. Heteroskedasticity and autocorrelation consistent covariance matrix estimation. Econometrica 59, 3 (May 1991), 817-58.

[2] Backus, D., Foresi, S., And Telmer, C. Affine term structure models and the forward premium anomaly. The Journal of Finance 56, 1 (2001), 279-304.

[3] Baele, L., Bekaert, G., And Inghelbrecht, K. The determinants of stock and bond return comovements. Review of Financial Studies 23, 6 (2010), 2374-2428.

[4] Bali, T. G., And Zhou, H. Risk, uncertainty, and expected returns. Finance and Economics Discussion Series 2011-45, Board of Governors of the Federal Reserve System (U.S.), 2011.

[5] Bansal, R., Khatchatrian, V., And Yaron, A. Interpretable asset markets? European Economic Review 49, 3 (2005), 531 - 560.

[6] Bansal, R., And Shaliastovich, I. A long-run risks explanation of predictability puzzles in bond and currency markets. Manuscript, Fuqua School of Business, Duke University (2010).

[7] Bansal, R., And Yaron, A. Risks for the long run: A potential resolution of asset pricing puzzles. Journal of Finance 59, 4 (08 2004), 1481-1509.

[8] Beeler, J., And Campbell, J. Y. The long-run risks model and aggregate asset prices: An empirical assessment. NBER Working Papers 14788, National Bureau of Economic Research, Inc, Mar. 2009.

[9] BekAert, G. The time variation of risk and return in foreign exchange markets: A general equilibrium perspective. Review of Financial Studies 9, 2 (1996), 427-70.

[10] Bekaert, G., And Hodrick, R. J. Characterizing predictable components in excess returns on equity and foreign exchange markets. The Journal of Finance 47, 2 (1992), pp. 467-509.

[11] Bollerslev, T., Marrone, J., Xu, L., And Zhou, H. Stock return predictability and variance risk premia: Statistical inference and international evidence. SSRN eLibrary (2011).

[12] Bollerslev, T., Tauchen, G., and Zhou, H. Expected stock returns and variance risk premia. Review of Financial Studies 22, 11 (2009), 4463-4492. 
[13] Britten-Jones, M., And Neuberger, A. Option prices, implied price processes, and stochastic volatility. Journal of Finance 55, 2 (04 2000), 839-866.

[14] Campbell, J., And Shiller, R. The dividend-price ratio and expectations of future dividends and discount factors. Review of financial studies 1, 3 (1988), 195228.

[15] Cappiello, L., And De Santis, R. A. Explaining exchange rate dynamics: The uncovered equity return parity condition. SSRN eLibrary (2005).

[16] Carr, P., And Wu, L. Variance risk premiums. Review of Financial Studies 22, 3 (2009), 1311-1341.

[17] Cochrane, J. H. Asset Pricing. Princeton University Press, 2005.

[18] Cochrane, J. H. Presidential address: Discount rates. Journal of Finance 66, 4 (08 2011), 1047-1108.

[19] Colacito, R., And Croce, M. M. Risks for the long run and the real exchange rate. Journal of Political Economy 119, 1 (2011), 153 - 181.

[20] Constantinides, G. M., And Ghosh, A. Asset pricing tests with long-run risks in consumption growth. Review of Asset Pricing Studies 1, 1 (2011), 96-136.

[21] Del Negro, M. Aggregate risk sharing across us states and across european countries. Working paper, Yale University, January 1998.

[22] Del Negro, M. Asymmetric shocks among u.s. states. Journal of International Economics 56, 2 (March 2002), 273-297.

[23] Drechsler, I., And Yaron, A. What's vol got to do with it. Review of Financial Studies 24, 1 (2011), 1-45.

[24] Engel, C. The forward discount anomaly and the risk premium: A survey of recent evidence. Journal of Empirical Finance 3, 2 (June 1996), 123-192.

[25] FAMA, E. The information in the term structure. Journal of financial economics 13, 4 (1984), 509-528.

[26] Hasseltoft, H. Stocks, bonds, and long-run consumption risks. Journal of Financial \& Quantitative Analysis 47, 2 (2012), 309 - 332.

[27] Hau, H., And Rey, H. Exchange rates, equity prices, and capital flows. Review of Financial Studies 19, 1 (Spring 2006), 273-317. 
[28] Hess, G. D., And Shin, K. Intranational business cycles in the united states. Journal of International Economics 44, 2 (April 1998), 289-313.

[29] Hess, G. D., And Shin, K. Understanding the backus-smith puzzle: It's the (nominal) exchange rate, stupid. Journal of International Money and Finance 29, 1 (February 2010), 169-180.

[30] Jiang, G. J., And Tian, Y. S. The model-free implied volatility and its information content. Review of Financial Studies 18, 4 (Winter 2005), 1305-1342.

[31] Kandel, S., and Stambaugh, R. F. Expectations and volatility of consumption and asset returns. Review of Financial Studies 3, 2 (1990), 207-32.

[32] LAUterbaCH, B. Consumption volatility, production volatility, spot-rate volatility, and the returns on treasury bills and bonds. Journal of Financial Economics 24, 1 (September 1989), 155-179.

[33] Lustig, H., And Nieuwerburgh, S. V. How much does household collateral constrain regional risk sharing? Review of Economic Dynamics 13, 2 (April 2010), 265-294.

[34] Lustig, H., Roussanov, N., and Verdelhan, A. Countercyclical currency risk premia. Working Paper 16427, National Bureau of Economic Research, September 2010.

[35] Lustig, H., Roussanov, N., And Verdelhan, A. Common risk factors in currency markets. Review of Financial Studies 24, 11 (2011), 3731-3777.

[36] Lustig, H., And Verdelhan, A. The cross section of foreign currency risk premia and consumption growth risk. American Economic Review 97, 1 (2007), 89-117.

[37] Meese, R. A., And Rogoff, K. Empirical exchange rate models of the seventies : Do they fit out of sample? Journal of International Economics 14, 1-2 (February 1983), 3-24.

[38] Menkhoff, L., Sarno, L., Schmeling, M., and Schrimpf, A. Carry trades and global foreign exchange volatility. Journal of Finance 67, 2 (04 2012), 681-718.

[39] Mueller, P., Vedolin, A., And Zhou, H. Short-run bond risk premia. SSRN eLibrary (2011).

[40] Newey, W. K., And West, K. D. A simple, positive semi-definite, heteroskedasticity and autocorrelation consistent covariance matrix. Econometrica 55, 3 (May 1987), 703-08. 
[41] Nicolin, P. Variance risk premiums in currency options.

[42] Osterganrd, C., Serensen, B. E., And Yosha, O. Consumption and aggregate constraints: Evidence from u.s. states and canadian provinces. Journal of Political Economy 110, 3 (June 2002), 634-645.

[43] Rogoff, K. Exchange rates in the modern floating era: what do we really know? Review of World Economics (Weltwirtschaftliches Archiv) 145, 1 (April 2009), 1-12.

[44] Rogoff, K. S., and Stavrakeva, V. The continuing puzzle of short horizon exchange rate forecasting. NBER Working Papers 14071, National Bureau of Economic Research, Inc, June 2008.

[45] Santa-Clara, P., And Yan, S. Crashes, volatility, and the equity premium: Lessons from s\&p 500 options. The Review of Economics and Statistics 92, 2 (07 2010), 435-451.

[46] Stock, J. H., And Watson, M. W. Has the business cycle changed and why? NBER Macroeconomics Annual 17 (2002), pp. 159-218.

[47] Stock, J. H., And Watson, M. W. Has the business cycle changed and why? In NBER Macroeconomics Annual 2002, Volume 17, NBER Chapters. National Bureau of Economic Research, Inc, 2003, pp. 159-230.

[48] Todorov, V. Variance risk-premium dynamics: The role of jumps. Review of Financial Studies 23, 1 (2010), 345-383.

[49] Verdelhan, A. A habit-based explanation of the exchange rate risk premium. Journal of Finance 65, 1 (2010), 123-146.

[50] Verdelhan, A. The share of systematic variation in bilateral exchange rates. SSRN eLibrary (2012).

[51] Welch, I., And Goyal, A. A comprehensive look at the empirical performance of equity premium prediction. Review of Financial Studies 21, 4 (July 2008), 14551508.

[52] Wilcox, D. W. Social security benefits, consumption expenditure, and the life cycle hypothesis. Journal of Political Economy 97, 2 (April 1989), 288-304.

[53] Zhоu, H. Variance risk premia, asset predictability puzzles, and macroeconomic uncertainty. Federal Reserve Board, Working Paper (2009). 


\section{Appendix A}

In this appendix, I use a global variance risk premium model similar to Bollerslev et al. (2011) in order to measure the variance of logarithm of stochastic discount factor.

I assume that the geometric growth rate of global consumption, $g_{t+1}^{g l}=\log \left(c_{t+1}^{g l} / c_{t}^{g l}\right)$, the global consumption growth volatility, $\sigma_{g, t+1}^{g l}$, and the global variance risk premium, $q_{t+1}^{g l}$, follow a joint process:

$$
\begin{gathered}
g_{t+1}^{g l}=\mu_{g}^{g l}+\sigma_{g, t}^{g l} z_{g, t+1}^{g l}, \\
\sigma_{g, t+1}^{g l^{2}}=a_{\sigma}^{g l}+\nu_{\sigma}^{g l} \sigma_{g, t+1}^{g 2^{2}}+\sqrt{q_{t}^{g l}} z_{\sigma, t+1}^{g l} \\
q_{t+1}^{g l}=a_{q}^{g l}+\nu_{q}^{g l} q_{t}^{g l}+\varphi_{q}^{g l} \sqrt{q_{t}^{g l}} z_{q, t+1}^{g l}
\end{gathered}
$$

Also, I assume that the geometric growth rate of country-specific consumptions, $g_{t+1}^{s i}=$ $\log \left(c_{t+1}^{s i} / c_{t}^{s i}\right)$, the country-specific consumption growth volatilities, $\sigma_{g, t+1}^{s i}$, and the countryspecific VRPs, $q_{t+1}^{s i}$, follow a similar joint process:

$$
\begin{gathered}
g_{t+1}^{s i}=\mu_{g}^{s i}+\sigma_{g, t}^{s i} z_{g, t+1}^{s i}, \\
\sigma_{g, t+1}^{s i^{2}}=a_{\sigma}^{s i}+\nu_{\sigma}^{s i} \sigma_{g, t+1}^{s i^{2}}+\sqrt{q_{t}^{s i}} z_{\sigma, t+1}^{s i} \\
q_{t+1}^{s i}=a_{q}^{s i}+\nu_{q}^{s i} q_{t}^{s i}+\varphi_{q}^{s i} \sqrt{q_{t}^{s i}} z_{q, t+1}^{s i}
\end{gathered}
$$

Where country $i \in\{$ US, UK, Japan, Europe, and Switzerland $\}$ in my data. Moreover, I assume that the country-specific components are uncorrelated across countries.

Bollerslev et al. (2009 \& 2011) assume that the representative agent in the economy has Epstein-Zin-Weil recursive preferences. Therefore, the logarithm of the stochastic discount factor of the representative agent is:

$$
m_{t+1}=\theta \log (\delta)-\frac{\theta}{\psi} g_{t+1}+(\theta-1) r_{t+1}
$$

where, $\theta \equiv \frac{(1-\gamma)}{(1-1 / \psi)}, \delta$ denotes the subjective discount factor, $\psi$ equals the intertemporal elasticity of substitution, $\gamma$ refers to the coefficient of risk aversion, and $r_{t+1}$ is the time $\mathrm{t}$ to $\mathrm{t}+1$ return on the consumption asset.

Moreover, I assume that the global and country-specific logarithm of the price-consumption $p c_{t}^{g l} \& p c_{t}^{s i}$ ratio of the asset that pays the consumption endowment has a conjecturing solution that is an affine function of the state variables:

$$
p c_{t}^{g l}=A_{0}^{g l}+A_{\sigma}^{g l} \sigma_{g, t+1}^{g l^{2}}+A_{q}^{g l} q_{t}^{g l}
$$




$$
p c_{t}^{s i}=A_{0}^{s i}+A_{\sigma}^{s i} \sigma_{g, t+1}^{s i^{2}}+A_{q}^{s i} q_{t}^{s i}
$$

Similar to Bollerslev et al. (2011) I use standard Campbell and Shiller (1988) loglinearization of returns;

$$
\begin{aligned}
& r_{t+1}^{g l}=\kappa_{0}^{g l}+\kappa_{1}^{g l} p c_{t+1}^{g l}-p c_{t}^{g l}+g_{t+1}^{g l} \\
& r_{t+1}^{s i}=\kappa_{0}^{s i}+\kappa_{1}^{s i} p c_{t+1}^{s i}-p c_{t}^{s i}+g_{t+1}^{s i}
\end{aligned}
$$

(where $r_{t+1}^{g l}$ and $r_{t+1}^{s i}$ are global and country-specific returns respectively), and a standard no-arbitrage condition $E_{t}\left[\exp \left(r_{t+1}+m_{t+1}\right)\right]=0$, to find these equilibrium solution for the coefficients:

$$
\begin{gathered}
A_{0}^{g l}=\frac{\log \delta+(1-1 / \psi) \mu_{g}^{g l}+\kappa_{0}^{g l}+\kappa_{1}^{g l}\left[A_{\sigma}^{g l} a_{\sigma}^{g l}+A_{q}^{g l} a_{q}^{g l}\right]}{\left(1-\kappa_{1}^{g l}\right)} \\
A_{\sigma}^{g l}=\frac{(1-\gamma)^{2}}{2 \theta\left(1-\kappa_{1}^{g l} \nu_{\sigma}^{g l}\right)} \\
A_{q}^{g l}=\frac{1-\kappa_{1}^{g l} \nu_{q}^{g l}-\sqrt{\left(1-\kappa_{1}^{g l} \nu_{q}^{g l}\right)^{2}-\theta^{2} \kappa_{1}^{g l^{4}} \varphi_{q}^{g l^{2}} A_{\sigma}^{g l^{2}}}}{\theta \kappa_{1}^{g l^{2}} \varphi_{q}^{g l^{2}}}
\end{gathered}
$$

and

$$
\begin{gathered}
A_{0}^{s i}=\frac{\log \delta+(1-1 / \psi) \mu_{g}^{s i}+\kappa_{0}^{s i}+\kappa_{1}^{s i}\left[A_{\sigma}^{s i} a_{\sigma}^{s i}+A_{q}^{s i} a_{q}^{s i}\right]}{\left(1-\kappa_{1}^{s i}\right)} \\
A_{\sigma}^{s i}=\frac{(1-\gamma)^{2}}{2 \theta\left(1-\kappa_{1}^{s i} \nu_{\sigma}^{s i}\right)} \\
A_{q}^{s i}=\frac{1-\kappa_{1}^{s i} \nu_{q}^{s i}-\sqrt{\left(1-\kappa_{1}^{s i} \nu_{q}^{s i}\right)^{2}-\theta^{2} \kappa_{1}^{s i^{4}} \varphi_{q}^{s i^{2}} A_{\sigma}^{s i 2}}}{\theta \kappa_{1}^{s i^{2}} \varphi_{q}^{s i^{2}}}
\end{gathered}
$$

Therefore, combining the statements for $r_{t+1}^{g l} \& p c_{t}^{g l}$, and $r_{t+1}^{s i} \& p c_{t}^{s i}$, and substituting the equilibrium coefficients, I get:

$r_{t+1}^{g l}=-\log \delta-\frac{\mu_{g}^{g l}}{\psi^{g l}}-\frac{(1-\gamma)^{2}}{(2 \theta)} \sigma_{g, t}^{g l}+\left(\kappa_{1}^{g l} \rho_{q}^{g l}-1\right) A_{q}^{g l} q_{t}^{g l}+\sigma_{g, t}^{g l} z_{g, t+1}^{g l}+\kappa_{1}^{g l} \sqrt{q_{t}^{g l}}\left[A_{\sigma}^{g l} z_{\sigma, t+1}^{g l}+A_{q}^{g l} \varphi_{q}^{g l} z_{q, t+1}^{g l}\right]$ 
and $r_{t+1}^{s i}=-\log \delta-\frac{\mu_{g}^{s i}}{\psi^{s i}}-\frac{(1-\gamma)^{2}}{(2 \theta)} \sigma_{g, t}^{s i}+\left(\kappa_{1}^{s i} \rho_{q}^{s i}-1\right) A_{q}^{s i} q_{t}^{s i}+\sigma_{g, t}^{s i} z_{g, t+1}^{s i}+\kappa_{1}^{s i} \sqrt{q_{t}^{s i}}\left[A_{\sigma}^{s i} z_{\sigma, t+1}^{s i}+A_{q}^{s i} \varphi_{q}^{s i} z_{q, t+1}^{s i}\right]$

Moreover, calculating VRPs similar to Bollerslev et al. (2009 \& 2011), I get:

$$
V R P_{t}^{g l} \approx(\theta-1) \kappa_{1}\left[\kappa_{1}^{g l^{2}} A_{q}^{g l} \varphi_{q}^{g l^{2}}\left(A_{\varphi}^{g l^{2}}+A_{q}^{g l^{2}} \varphi_{q}^{g l^{2}}\right)+A_{\varphi}^{g l} \varphi_{q}\right] q_{t}^{g l}
$$

and

$$
V R P_{t}^{s i} \approx(\theta-1) \kappa_{1}\left[\kappa_{1}^{s i^{2}} A_{q}^{s i} \varphi_{q}^{s i^{2}}\left(A_{\varphi}^{s i^{2}}+A_{q}^{s i^{2}} \varphi_{q}^{s i^{2}}\right)+A_{\varphi}^{s i} \varphi_{q}\right] q_{t}^{s i}
$$

Finally, I assume that the observed consumptions, returns, consumption growth, and variance risk premiums are a function of the global and the country-specific components:

$$
\begin{gathered}
c_{t}^{i}=\vartheta_{c}^{i}+\tau_{c}^{i} \times c_{t}^{g l}+c_{t}^{s i}, \\
g_{t}^{i}=\vartheta_{g}^{i}+\tau_{g}^{i} \times g_{t}^{g l}+g_{t}^{s i}, \\
r_{t}^{i}=\vartheta_{r}^{i}+\tau_{r}^{i} \times r_{t}^{g l}+r_{t}^{s i}, \\
V R P_{t}^{i}=\vartheta_{V R P}^{i}+\tau_{V R P}^{i} \times V R P_{t}^{g l}+V R P_{t}^{s i},
\end{gathered}
$$

Next, I calculate the variance of logarithm of stochastic discount factor in country i:

$$
\begin{gathered}
\operatorname{var}\left[m_{t+1}^{i}\right]=\operatorname{var}\left[\theta \log (\delta)-\frac{\theta}{\psi} g_{t+1}^{i}+(\theta-1) r_{t+1}^{i}\right] \\
\operatorname{var}\left[m_{t+1}\right]=\left(\frac{\theta}{\psi}\right)^{2} \operatorname{var}\left(g_{t+1}^{i}\right)+(\theta-1)^{2} \operatorname{var}\left(r_{t+1}^{i}\right)-2\left(\frac{\theta}{\psi}\right)(\theta-1) \operatorname{cov}\left(g_{t+1}^{i}, r_{t+1}^{i}\right) \\
\operatorname{var}\left[m_{t+1}\right]=\left(\frac{\theta}{\psi}\right)^{2}\left[\tau_{g}^{i^{2}} \operatorname{var}\left(g_{t+1}^{g l}\right)+\operatorname{var}\left(g_{t+1}^{s i}\right)\right]+(\theta-1)^{2}\left[\tau_{r}^{i^{2}} \operatorname{var}\left(r_{t+1}^{g l}\right)+\operatorname{var}\left(r_{t+1}^{s i}\right)\right] \\
-2\left(\frac{\theta}{\psi}\right)(\theta-1)\left[\operatorname{cov}\left(g_{t+1}^{g l}, r_{t+1}^{g l}\right)+\operatorname{cov}\left(g_{t+1}^{g l}, r_{t+1}^{s i}\right)+\operatorname{cov}\left(g_{t+1}^{s i}, r_{t+1}^{g l}\right)+\operatorname{cov}\left(g_{t+1}^{s i}, r_{t+1}^{s i}\right)\right] \\
+(\theta-1)^{2}\left[\tau_{r}^{i^{2}}\left(\sigma_{g, t}^{g l}{ }^{2}+\kappa_{1}^{g l^{2}}\left(A_{\sigma}^{g l^{2}}+A_{q}^{g{ }^{2}} \varphi_{q}^{g l^{2}}\right) q_{t}^{g l}\right)+\left(\sigma_{g, t}^{s i}{ }^{2}+\kappa_{1}^{s 2^{2}}\left(A_{\sigma}^{s i^{2}}+A_{q}^{s i^{2}} \varphi_{q}^{s i^{2}}\right) q_{t}^{s i}\right)\right] \\
-2\left(\frac{\theta}{\psi}\right)(\theta-1)\left[\tau_{g}^{i^{2}} \sigma_{g, t}^{g l^{2}}+\sigma_{g, t}^{s i^{2}}\right]
\end{gathered}
$$




$$
\begin{gathered}
\operatorname{var}\left[m_{t+1}\right]=\left(\left(\frac{\theta}{\psi}\right)^{2}+(\theta-1)^{2}-2\left(\frac{\theta}{\psi}\right)(\theta-1)\right)\left[\tau_{g}^{i^{2}} \sigma_{g, t}^{g l^{2}}+\sigma_{g, t}^{s i^{2}}\right] \\
+(\theta-1)^{2}\left\{\tau_{r}^{i^{2}} \kappa_{1}^{g l^{2}}\left(A_{\sigma}^{g l^{2}}+A_{q}^{g l^{2}} \varphi_{q}^{g l^{2}}\right)\left[q_{t}^{g l}\right]+\kappa_{1}^{s i^{2}}\left(A_{\sigma}^{s i^{2}}+A_{q}^{s 2^{2}} \varphi_{q}^{s i^{2}}\right)\left[q_{t}^{s i}\right]\right\} \\
\operatorname{var}\left[m_{t+1}\right]=\gamma^{2}\left[\tau_{g}^{i^{2}} \times \sigma_{g, t}^{g l^{2}}\right]+\gamma^{2}\left[\sigma_{g, t}^{s i^{2}}\right] \\
+(\theta-1)^{2} \kappa_{1}^{g l^{2}}\left(A_{\sigma}^{g l^{2}}+A_{q}^{g l^{2}} \varphi_{q}^{g 2^{2}}\right)\left[\tau_{r}^{i^{2}} \times q_{t}^{g l}\right]+(\theta-1)^{2} \kappa_{1}^{s i^{2}}\left(A_{\sigma}^{s i^{2}}+A_{q}^{s i^{2}} \varphi_{q}^{s i{ }^{2}}\right)\left[q_{t}^{s i}\right]
\end{gathered}
$$

Therefore, variance of logarithm of stochastic discount factor is a function of function of the global and the country-specific components. This means, that we can write the expected excess foreign exchange returns as a function of function of the global and the country-specific components as well:

If

$$
\begin{aligned}
& V R P_{t}^{g l} \equiv(\theta-1) \kappa_{1}\left[\kappa_{1}^{g l^{2}} A_{q}^{g l} \varphi_{q}^{g l^{2}}\left(A_{\varphi}^{g l^{2}}+A_{q}^{g l^{2}} \varphi_{q}^{g l^{2}}\right)+A_{\varphi}^{g l} \varphi_{q}\right] q_{t}^{g l} \\
& \bigwedge \\
& V R P_{t}^{s i} \equiv(\theta-1) \kappa_{1}\left[\kappa_{1}^{s i^{2}} A_{q}^{s i} \varphi_{q}^{s i^{2}}\left(A_{\varphi}^{s i^{2}}+A_{q}^{s i^{2}} \varphi_{q}^{s i^{2}}\right)+A_{\varphi}^{s i} \varphi_{q}\right] q_{t}^{s i}
\end{aligned}
$$

then

$$
\operatorname{var}\left[m_{t+1}\right]=\gamma^{2}\left[\tau_{g}^{i^{2}} \times \sigma_{g, t}^{g l^{2}}\right]+\gamma^{2}\left[{\sigma_{g, t}^{s i^{2}}}\right]+\lambda^{g l}\left[\tau_{r}^{i^{2}} \times V R P_{t}^{g l}\right]+\lambda^{s i}\left[V R P_{t}^{s i}\right]
$$

where

$$
\begin{aligned}
& \lambda^{g l}=\frac{(\theta-1)^{2} \kappa_{1}^{g 2^{2}}\left(A_{\sigma}^{g l^{2}}+A_{q}^{g l}{ }^{2} \varphi_{q}^{g l^{2}}\right)}{(\theta-1) \kappa_{1}\left[\kappa_{1}^{g l^{2}} A_{q}^{g l} \varphi_{q}^{g l^{2}}\left(A_{\varphi}^{g l^{2}}+A_{q}^{g l^{2}} \varphi_{q}^{g l^{2}}\right)+A_{\varphi}^{g l} \varphi_{q}\right]} \\
& \bigwedge \\
& \lambda^{s i}=\frac{(\theta-1)^{2} \kappa_{1}^{s i}\left(A_{\sigma}^{s i^{2}}+A_{q}^{s i^{2}} \varphi_{q}^{s i^{2}}\right)\left[q_{t}^{s i}\right]}{(\theta-1) \kappa_{1}\left[\kappa_{1}^{s i^{2}} A_{q}^{s i} \varphi_{q}^{s i^{2}}\left(A_{\varphi}^{s i^{2}}+A_{q}^{s i^{2}} \varphi_{q}^{s i^{2}}\right)+A_{\varphi}^{s i} \varphi_{q}\right]}
\end{aligned}
$$

moreover, the expected excess foreign exchange return betwee country $i$ and $j$ is

$$
E\left[r x_{i j, t}^{f x}\right]=\frac{1}{2} \operatorname{var}\left[m_{t+1}^{i}\right]-\frac{1}{2} \operatorname{var}\left[m_{t+1}^{j}\right]
$$

if we assume that the subjective discount factors and subjective discount factors and the coefficients of VRPs are the same across two countries, $\mathrm{i}$ and $\mathrm{j}$ :

$\lambda_{i}^{g l}=\lambda_{j}^{g l} \bigwedge \lambda_{i}^{s i}=\lambda_{j}^{s i} \bigwedge \gamma_{i}^{s i}=\gamma_{j}^{s i}$, then

$$
\begin{gathered}
E\left[r x_{i j, t}^{f x}\right]=\frac{1}{2} \gamma^{2}\left[\tau_{g}^{i^{2}} \times \sigma_{g, t}^{g l^{2}}\right]+\frac{1}{2} \gamma^{2}\left[\sigma_{g, t}^{s i^{2}}\right]+\frac{1}{2} \lambda^{g l}\left[\tau_{r}^{i^{2}} \times V R P_{t}^{g l}\right]+\frac{1}{2} \lambda^{s i}\left[V R P_{t}^{s i}\right] \\
-\frac{1}{2} \gamma^{2}\left[\tau_{g}^{j} \times \sigma_{g, t}^{g l^{2}}\right]-\frac{1}{2} \gamma^{2}\left[\sigma_{g, t}^{s j^{2}}\right]-\frac{1}{2} \lambda^{g l}\left[\tau_{r}^{j^{2}} \times V R P_{t}^{g l}\right]+\frac{1}{2} \lambda^{s j}\left[V R P_{t}^{s j}\right]
\end{gathered}
$$


rearranging the equation 14 , I get:

$$
\begin{gathered}
E\left[r x_{i j, t}^{f x}\right]=\frac{1}{2} \gamma^{2}\left(\tau_{g}^{i^{2}}-\tau_{g}^{j^{2}}\right)\left[\sigma_{g, t}^{g l^{2}}\right]+\frac{1}{2} \gamma^{2}\left[\sigma_{g, t}^{s i^{2}}-\sigma_{g, t}^{s j^{2}}\right] \\
+\frac{1}{2} \lambda^{g l}\left(\tau_{r}^{i^{2}}-\tau_{r}^{j^{2}}\right)\left[V R P_{t}^{g l}\right]+\frac{1}{2} \lambda^{s i}\left[V R P_{t}^{s i}-V R P_{t}^{s j}\right]
\end{gathered}
$$

This equation suggests that the excess foreign exchange return between country $\mathrm{i}$ and $\mathrm{j}$ is a function of the global consumption growth volatility, $\sigma_{g, t}^{g l^{2}}$, the cross-country countryspecific consumption growth volatility differential, $\sigma_{g, t}^{s i^{2}}-\sigma_{g, t}^{s j^{2}}$, the global variance risk premium, $V R P_{t}^{g l}$, and the country-specific variance risk premium differential, $V R P_{t}^{s i}-$ $V R P_{t}^{s j}$. 


\section{Appendix B}

The related variables for the monthly excess foreign exchange returns are:

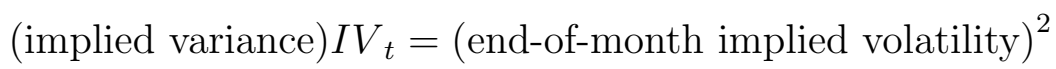

(realized variance) $R V_{t}=\sum$ (daily aggregate market indices in month $\left.\mathrm{t}\right)^{2}$ (variance risk premia) $V R P_{t}=I V_{t}-R V_{t}$

(variance risk premium differential) $D V R P_{t}=V R P_{t}-V R P_{t}^{*}$ (monthly excess exchange return) $r x_{t}^{f x}=s_{t+1}-s_{t}-r f_{t}+r f_{t}^{*}$

Where, $s_{t}$ stands for the logarithm of the end-of-month spot exchange rate, per unit of the foreign currency (for example, dollars spot price of one pound). And $r f_{t}\left(r f_{t}^{*}\right)$ is the the monthly interbank rate in the local (foreign) country. The corresponding regression is:

$$
r x_{t}^{f x}=\alpha+\beta \times D V R P_{t}+\varepsilon_{t}
$$

\section{Appendix $\mathrm{C}$}

The variables for the 1-month excess holding period returns for the interbank rates with n-month to maturity are:

(1-month excess holding period returns) $b p r_{t, 2}^{i b}=y_{t-1,2}-y_{t, 1}-y_{t-1,1}$

where, $y_{t, n}(n \in\{1,2\})$ an interbank return with n-month to maturity at time t. Then, the lagged forward spread is equal to:

$$
f s_{t-1}^{i b}(1,2)=y_{t-1,2}-y_{t-1,1}
$$

where, $\left(f s_{t-1}^{i b}(1,2)-y_{t-1,2}\right)$ is the forward spread of a contract for (2)-month ahead with (1)-month length. Therefore, I run the following regression:

$$
b p r_{t, 2}^{i b}=\alpha^{\prime}+\beta^{\prime} \times\left(f s_{t-1}^{i b}(1,2)-y_{t-1,2}\right)+\gamma^{\prime} \times V R P_{t}^{s}+\varepsilon^{\prime}{ }_{t}
$$




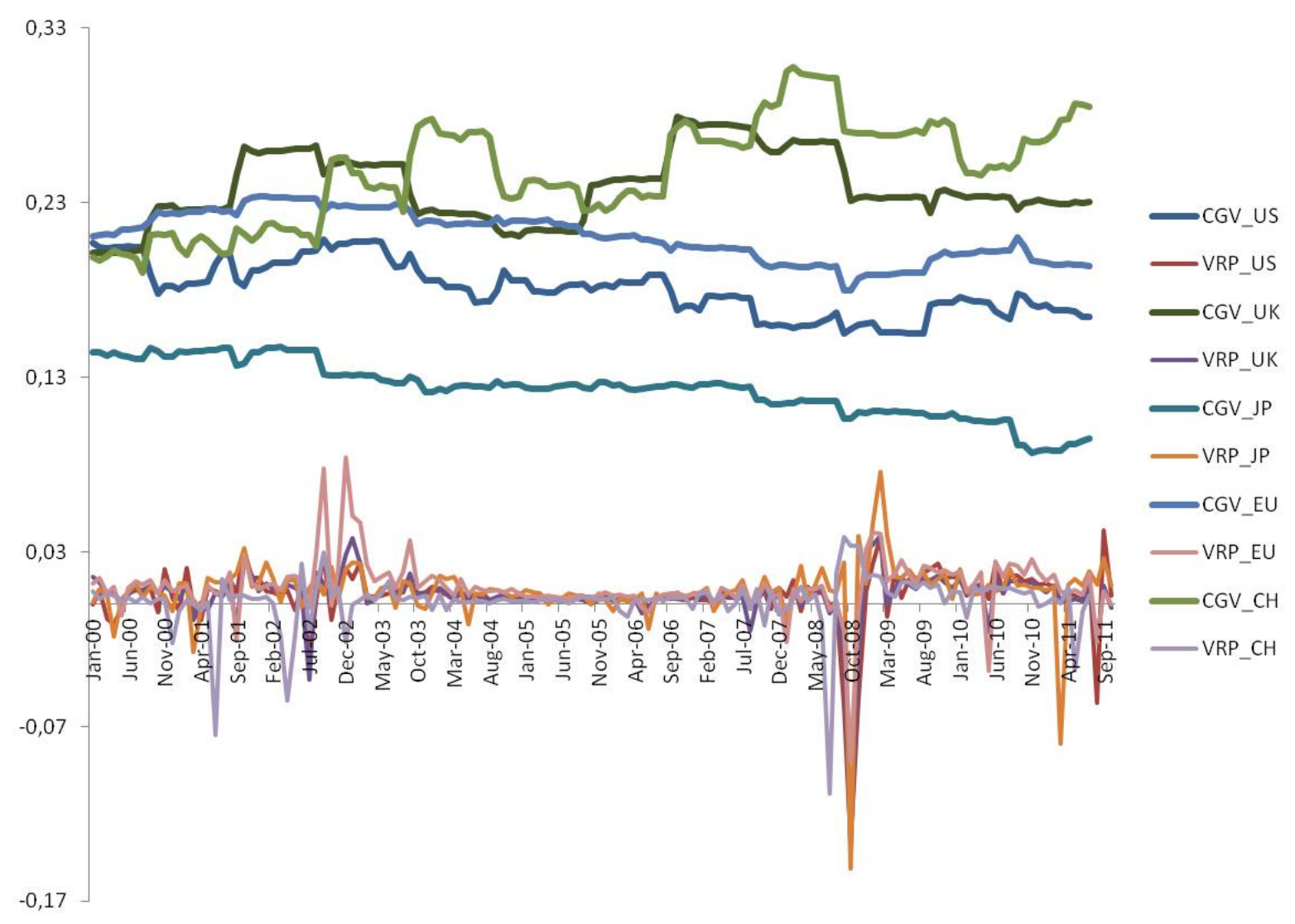

Figure 1: Monthly consumption growth volatility (CGV) and monthly variance risk premium (VRP) in the US (US), the UK (UK), Japan (JP), Europe (EU), and Switzerland $(\mathrm{CH})$ on the sample periods from January 2005 to October 2011. Consumption growth volatilities are constructed as a 2-year sum of absolute residuals from $\operatorname{AR}(3)$ projections of monthly retail sale growth rates; similar to following Bansal et al. (2005). Variance risk premiums are measured by the difference between one-month forward looking model-free options implied variances and the actual one-month realized variances at the time, as in Bollerslev et al. (2009) 


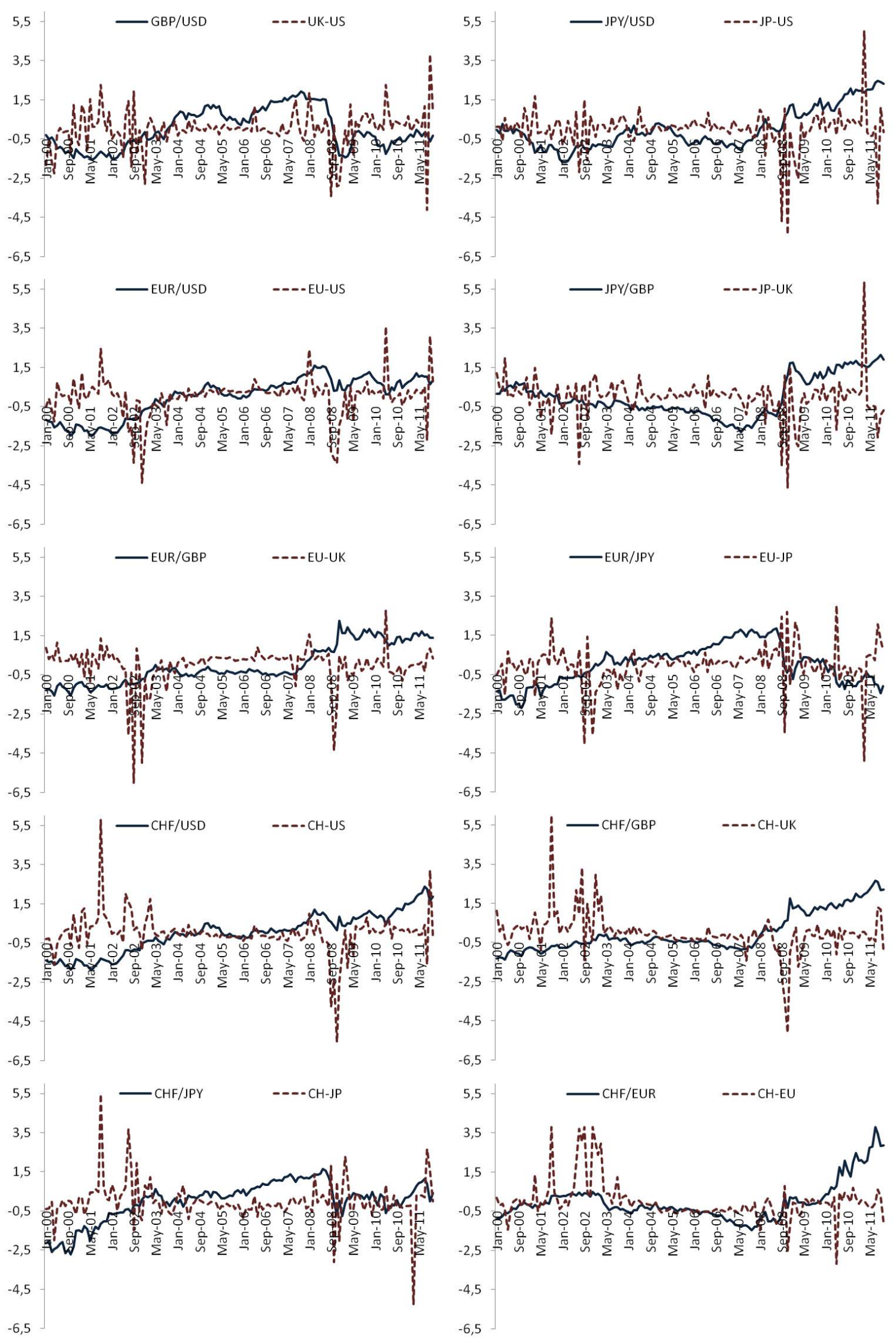

Figure 2: Cross Country VRP Differentials and Spot Exchange Rates. All variables are standardized (demeaned and divided by standard deviation). 


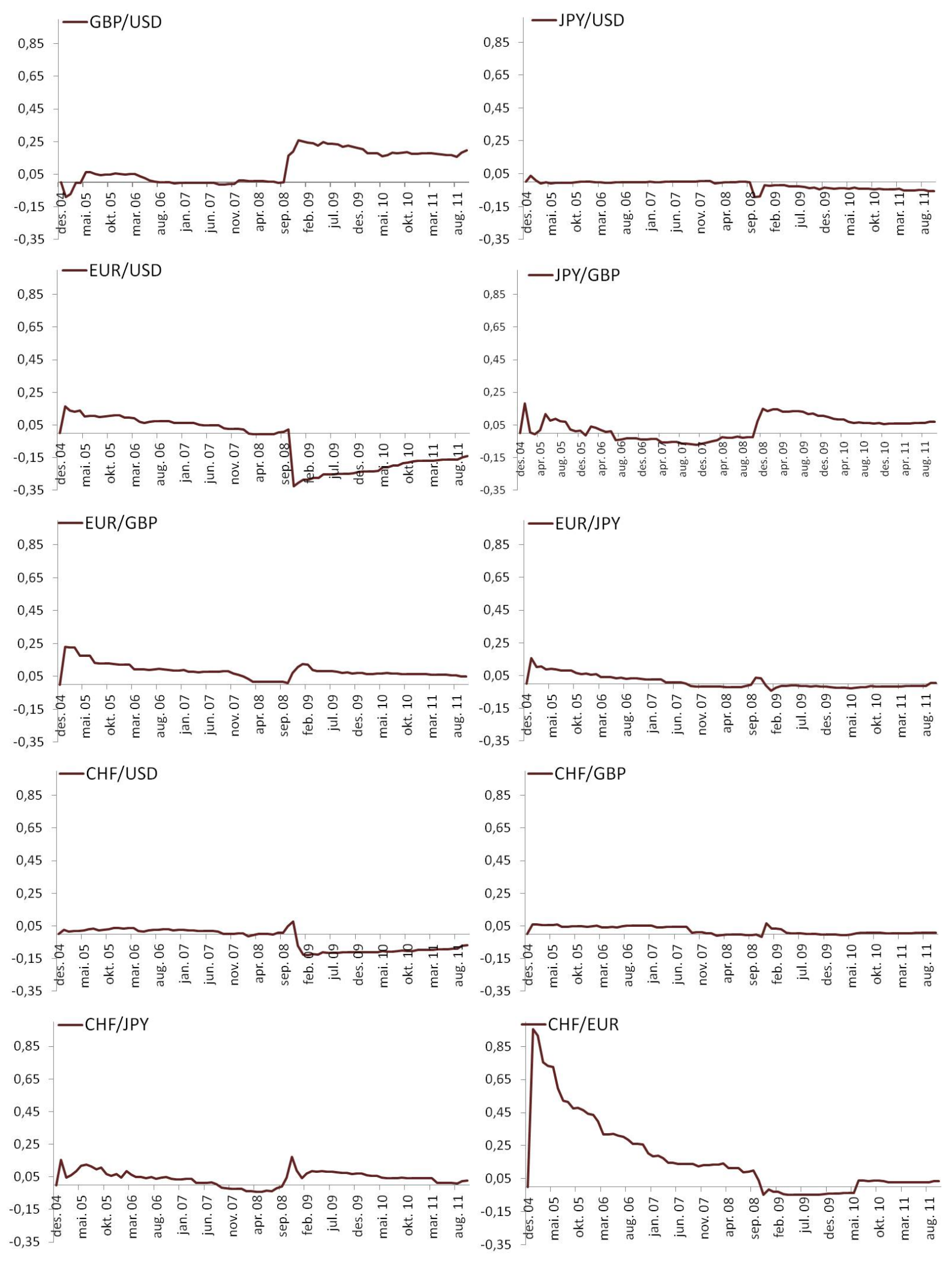

Figure 3: Out-of-sample $R^{2}$ for prediction based on monthly global VRP and country specific VRP differential on the sample periods from January 2005 to October 2011 (I use a 5-year training sample from January 2000 to December 2004). 
Table 1: Summary Statistics

\begin{tabular}{|c|c|c|c|c|c|c|}
\hline & Interest & Inflation & rInterest & ConGro & ConVol & VRP \\
\hline \multicolumn{7}{|l|}{ US } \\
\hline Mean & 22.7 & 20.7 & 2.1 & -9.5 & 18.2 & 9.4 \\
\hline S.D. & 17.8 & 11.2 & 15.4 & 10.4 & 1.6 & 35.0 \\
\hline $\operatorname{AR}(1)$ & 0.98 & 0.93 & 0.94 & -0.37 & 0.94 & 0.37 \\
\hline \multicolumn{7}{|l|}{ UK } \\
\hline Mean & 32.6 & 16.8 & 17.0 & -9.4 & 23.8 & 9.7 \\
\hline S.D. & 16.6 & 8.2 & 20.6 & 11.3 & 2.1 & 31.9 \\
\hline $\operatorname{AR}(1)$ & 0.98 & 0.97 & 0.99 & -0.23 & 0.96 & 0.33 \\
\hline \multicolumn{7}{|l|}{ Japan } \\
\hline Mean & 2.0 & -2.5 & 4.5 & -13.8 & 12.6 & 15.5 \\
\hline S.D. & 2.2 & 6.7 & 5.8 & 9.8 & 1.7 & 37.9 \\
\hline $\operatorname{AR}(1)$ & 0.95 & 0.93 & 0.91 & -0.36 & 0.99 & -0.01 \\
\hline \multicolumn{7}{|l|}{ Europe } \\
\hline Mean & 22.9 & 17.5 & 5.5 & -14.2 & 21.4 & 20.6 \\
\hline S.D. & 17.8 & 6.4 & 9.7 & 11.1 & 1.3 & 33.0 \\
\hline $\operatorname{AR}(1)$ & 0.95 & 0.94 & 0.96 & -0.34 & 0.98 & 0.32 \\
\hline \multicolumn{7}{|c|}{ Switzerland } \\
\hline Mean & 10.5 & 7.4 & 3.1 & -6.0 & 24.9 & 3.8 \\
\hline S.D. & 9.5 & 6.6 & 8.3 & 11.6 & 3.3 & 30.7 \\
\hline $\operatorname{AR}(1)$ & 0.98 & 0.90 & 0.92 & -0.25 & 0.96 & 0.13 \\
\hline
\end{tabular}

Monthly interest rates (Interest) and inflation rates (Inflation), Real interest rates (rInterest) or differences between interest rates and inflation rates (Interest minus Inflation) are in annualized basis-point form. The consumption is proxied by the retail sales. The log of consumption growth (ConGro) is in annualized basis-point form. The Consumption volatility (ConVol) is in annualized basis-point form. The variance risk premia are in monthly percentage-squared form. The common sample period extends from January 2000 to October 2011. 
Table 2: Summary Statistics

\begin{tabular}{|c|c|c|c|c|c|c|c|c|}
\hline Spot Rate & & $\mathrm{s}$ & $\mathrm{ds}$ & $\mathrm{di}$ & dri & $\mathrm{FX}$ & $\mathrm{rFX}$ & DVRP \\
\hline GBP/USD & $\begin{array}{l}\text { Mean (pp) } \\
\text { S.D. (pp) } \\
\text { AR(1) }\end{array}$ & $\begin{array}{l}51.45 \\
11.23 \\
0.972 \\
\end{array}$ & $\begin{array}{c}-0.00 \\
2.63 \\
0.120 \\
\end{array}$ & $\begin{array}{c}-0.10 \\
0.10 \\
0.962 \\
\end{array}$ & $\begin{array}{c}-0.14 \\
0.18 \\
0.962 \\
\end{array}$ & $\begin{array}{c}0.10 \\
2.63 \\
0.118 \\
\end{array}$ & $\begin{array}{c}0.15 \\
2.61 \\
0.133 \\
\end{array}$ & $\begin{array}{c}-0.00 \\
0.17 \\
-0.040 \\
\end{array}$ \\
\hline JPY/USD & $\begin{array}{l}\text { Mean (pp) } \\
\text { S.D. (pp) } \\
\text { AR(1) }\end{array}$ & $\begin{array}{c}-466.97 \\
13.51 \\
0.997 \\
\end{array}$ & $\begin{array}{c}0.22 \\
2.83 \\
-0.048\end{array}$ & $\begin{array}{c}.21 \\
0.17 \\
0.973\end{array}$ & $\begin{array}{c}-0.02 \\
0.15 \\
0.937 \\
\end{array}$ & $\begin{array}{c}0.02 \\
2.85 \\
-0.028\end{array}$ & $\begin{array}{c}0.26 \\
2.85 \\
-0.037\end{array}$ & $\begin{array}{c}-0.06 \\
0.34 \\
-0.083\end{array}$ \\
\hline EUR/USD & $\begin{array}{l}\text { Mean (pp) } \\
\text { S.D. (pp) } \\
\text { AR(1) }\end{array}$ & $\begin{array}{l}18.17 \\
17.53 \\
0.981 \\
\end{array}$ & $\begin{array}{c}0.25 \\
3.17 \\
0.046\end{array}$ & $\begin{array}{c}-0.00 \\
0.11 \\
0.977\end{array}$ & $\begin{array}{c}-0.03 \\
0.10 \\
0.908 \\
\end{array}$ & $\begin{array}{c}0.25 \\
3.17 \\
0.050\end{array}$ & $\begin{array}{c}0.29 \\
3.15 \\
0.040 \\
\end{array}$ & $\begin{array}{c}-0.11 \\
0.26 \\
0.371 \\
\end{array}$ \\
\hline $\mathrm{CHF} / \mathrm{USD}$ & $\begin{array}{l}\text { Mean (pp) } \\
\text { S.D. (pp) } \\
\text { AR(1) }\end{array}$ & $\begin{array}{c}-22.67 \\
19.49 \\
0.991 \\
\end{array}$ & $\begin{array}{c}0.45 \\
3.35 \\
-0.075 \\
\end{array}$ & $\begin{array}{c}0.12 \\
0.11 \\
0.962 \\
\end{array}$ & $\begin{array}{c}-0.13 \\
0.11 \\
0.921 \\
\end{array}$ & $\begin{array}{c}0.33 \\
3.36 \\
-0.069 \\
\end{array}$ & $\begin{array}{c}0.58 \\
3.36 \\
-0.075 \\
\end{array}$ & $\begin{array}{c}0.06 \\
0.17 \\
0.390 \\
\end{array}$ \\
\hline JPY/GBP & $\begin{array}{l}\text { Mean (pp) } \\
\text { S.D. (pp) } \\
\text { AR(1) }\end{array}$ & $\begin{array}{l}-5.18 \\
18.38 \\
0.993\end{array}$ & $\begin{array}{c}0.22 \\
3.68 \\
0.046\end{array}$ & $\begin{array}{c}0.30 \\
0.16 \\
0.973\end{array}$ & $\begin{array}{c}0.12 \\
0.22 \\
0.985 \\
\end{array}$ & $\begin{array}{c}-0.08 \\
3.68 \\
0.049\end{array}$ & $\begin{array}{c}0.07 \\
3.71 \\
0.049\end{array}$ & $\begin{array}{c}-0.06 \\
0.29 \\
-0.047\end{array}$ \\
\hline EUR/GBP & $\begin{array}{l}\text { Mean (pp) } \\
\text { S.D. (pp) } \\
\text { AR(1) }\end{array}$ & $\begin{array}{l}-33.28 \\
13.30 \\
0.982 \\
\end{array}$ & $\begin{array}{c}0.25 \\
2.56 \\
-0.105 \\
\end{array}$ & $\begin{array}{c}0.10 \\
0.08 \\
0.969 \\
\end{array}$ & $\begin{array}{c}0.11 \\
0.15 \\
0.981 \\
\end{array}$ & $\begin{array}{c}0.16 \\
2.56 \\
-0.104 \\
\end{array}$ & $\begin{array}{c}0.16 \\
2.57 \\
-0.082 \\
\end{array}$ & $\begin{array}{c}-0.11 \\
0.20 \\
0.203 \\
\end{array}$ \\
\hline $\mathrm{CHF} / \mathrm{GBP}$ & $\begin{array}{l}\text { Mean (pp) } \\
\text { S.D. (pp) } \\
\text { AR(1) }\end{array}$ & $\begin{array}{c}-74.12 \\
18.13 \\
0.998 \\
\end{array}$ & $\begin{array}{c}0.45 \\
2.98 \\
-0.122 \\
\end{array}$ & $\begin{array}{c}0.22 \\
0.11 \\
0.965 \\
\end{array}$ & $\begin{array}{c}0.13 \\
0.18 \\
0.981 \\
\end{array}$ & $\begin{array}{c}0.23 \\
2.99 \\
-0.119 \\
\end{array}$ & $\begin{array}{c}0.33 \\
2.93 \\
-0.151 \\
\end{array}$ & $\begin{array}{c}0.06 \\
0.20 \\
0.371 \\
\end{array}$ \\
\hline EUR/JPY & $\begin{array}{c}\text { Mean (pp) } \\
\text { S.D. (pp) } \\
\text { AR }(1)\end{array}$ & $\begin{array}{l}485.14 \\
14.76 \\
0.967\end{array}$ & $\begin{array}{c}0.03 \\
3.65 \\
-0.014\end{array}$ & $\begin{array}{c}-0.21 \\
0.11 \\
0.973\end{array}$ & $\begin{array}{c}-0.01 \\
0.11 \\
0.938\end{array}$ & $\begin{array}{c}0.24 \\
3.65 \\
-0.010\end{array}$ & $\begin{array}{c}0.00 \\
3.64 \\
0.004\end{array}$ & $\begin{array}{c}-0.05 \\
0.34 \\
-0.038\end{array}$ \\
\hline CHF/JPY & $\begin{array}{l}\text { Mean (pp) } \\
\text { S.D. (pp) } \\
\text { AR(1) }\end{array}$ & $\begin{array}{l}444.29 \\
12.36 \\
0.945 \\
\end{array}$ & $\begin{array}{c}0.22 \\
3.47 \\
-0.162 \\
\end{array}$ & $\begin{array}{c}-0.08 \\
0.09 \\
0.975 \\
\end{array}$ & $\begin{array}{c}0.01 \\
0.08 \\
0.898 \\
\end{array}$ & $\begin{array}{c}0.31 \\
3.47 \\
-0.160 \\
\end{array}$ & $\begin{array}{c}0.18 \\
3.45 \\
-0.138 \\
\end{array}$ & $\begin{array}{c}0.12 \\
0.32 \\
0.071 \\
\end{array}$ \\
\hline CHF/EUR & $\begin{array}{c}\text { Mean (pp) } \\
\text { S.D. (pp) } \\
\text { AR }(1)\end{array}$ & $\begin{array}{c}-40.84 \\
7.46 \\
0.996\end{array}$ & $\begin{array}{c}0.20 \\
1.83 \\
-0.183\end{array}$ & $\begin{array}{c}0.12 \\
0.05 \\
0.930\end{array}$ & $\begin{array}{c}0.02 \\
0.06 \\
0.980\end{array}$ & $\begin{array}{c}0.08 \\
1.84 \\
-0.175\end{array}$ & $\begin{array}{c}0.18 \\
1.83 \\
-0.179\end{array}$ & $\begin{array}{c}0.17 \\
0.24 \\
0.563\end{array}$ \\
\hline
\end{tabular}

This table reports the average end-of-the-month log spot rate (s), the average change in log spot exchange rate (ds), the average interest rate differential (di), and average real interest rate differential (dri), the average log excess foreign exchange returns (FX), the average log excess real foreign exchange returns $(\mathrm{rFX})$, and the average variance risk premium differentials (DVRP). Log excess foreign exchange returns are computed as $F X=d s-d i$. All moments are annualized and reported in percentage points. Data are monthly, from Datastream. The common sample period extends from January 2000 to October 2011. 
Table 3: Correlations

\begin{tabular}{|c|c|c|c|c|}
\hline GBP/USD & $V R P_{U S}$ & $V R P_{U K}$ & DVRP & ds \\
\hline$V R P_{U K}$ & 0.879 & & & \\
\hline DVRP & 0.414 & -0.071 & & \\
\hline $\mathrm{ds}$ & 0.389 & 0.250 & 0.337 & \\
\hline FX & 0.385 & 0.247 & 0.336 & 0.999 \\
\hline JPY/USD & $V R P_{U S}$ & $V R P_{J a p a n}$ & DVRP & $\mathrm{ds}$ \\
\hline$V R P_{\text {Japan }}$ & 0.571 & & & \\
\hline DVRP & 0.394 & -0.529 & & \\
\hline $\mathrm{ds}$ & -0.178 & -0.128 & -0.041 & \\
\hline $\mathrm{FX}$ & -0.168 & -0.116 & -0.044 & 0.998 \\
\hline EUR/USD & $V R P_{U S}$ & $V R P_{\text {Europe }}$ & DVRP & ds \\
\hline$V R P_{\text {Europe }}$ & 0.706 & & & \\
\hline DVRP & 0.449 & -0.317 & & \\
\hline ds & 0.157 & 0.115 & 0.066 & \\
\hline FX & 0.157 & 0.121 & 0.057 & 0.999 \\
\hline $\mathrm{CHF} / \mathrm{USD}$ & $V R P_{U S}$ & $V R P_{\text {Swiss }}$ & DVRP & $\mathrm{ds}$ \\
\hline$V R P_{\text {Swiss }}$ & 0.668 & & & \\
\hline DVRP & 0.533 & -0.273 & & \\
\hline $\mathrm{ds}$ & 0.174 & 0.156 & 0.048 & \\
\hline $\mathrm{FX}$ & 0.179 & 0.157 & 0.052 & 0.999 \\
\hline JPY/GBP & $V R P_{U K}$ & $V R P_{\text {Japan }}$ & DVRP & ds \\
\hline$V R P_{\text {Japan }}$ & 0.674 & & & \\
\hline DVRP & 0.223 & -0.570 & & \\
\hline $\mathrm{ds}$ & -0.308 & -0.119 & -0.185 & \\
\hline FX & -0.301 & -0.111 & -0.188 & 0.999 \\
\hline
\end{tabular}

(Continued on next page) 
Table 3: Correlations

\begin{tabular}{|c|c|c|c|c|}
\hline EUR/GBP & $V R P_{U K}$ & $V R P_{\text {Europe }}$ & DVRP & ds \\
\hline$V R P_{\text {Europe }}$ & 0.810 & & & \\
\hline DVRP & 0.262 & -0.354 & & \\
\hline $\mathrm{ds}$ & -0.202 & -0.072 & -0.204 & \\
\hline $\mathrm{FX}$ & -0.198 & -0.065 & -0.209 & 0.999 \\
\hline $\mathrm{CHF} / \mathrm{GBP}$ & $V R P_{U K}$ & $V R P_{\text {Swiss }}$ & DVRP & $\mathrm{ds}$ \\
\hline$V R P_{\text {Swiss }}$ & 0.801 & & & \\
\hline DVRP & 0.368 & -0.262 & & \\
\hline $\mathrm{ds}$ & -0.143 & 0.030 & -0.277 & \\
\hline $\mathrm{FX}$ & -0.136 & 0.037 & -0.276 & 0.999 \\
\hline EUR/JPY & $V R P_{\text {Japan }}$ & $V R P_{\text {Europe }}$ & DVRP & ds \\
\hline$V R P_{\text {Europe }}$ & 0.541 & & & \\
\hline DVRP & 0.587 & -0.364 & & \\
\hline ds & 0.097 & 0.189 & -0.074 & \\
\hline FX & 0.093 & 0.183 & -0.073 & 0.999 \\
\hline $\mathrm{CHF} / \mathrm{JPY}$ & $V R P_{\text {Japan }}$ & $V R P_{\text {Swiss }}$ & DVRP & ds \\
\hline$V R P_{\text {Swiss }}$ & 0.587 & & & \\
\hline DVRP & 0.623 & -0.267 & & \\
\hline ds & 0.174 & 0.172 & 0.041 & \\
\hline FX & 0.171 & 0.168 & 0.042 & 0.999 \\
\hline $\mathrm{CHF} / \mathrm{EUR}$ & $V R P_{E U R}$ & $V R P_{\text {Swiss }}$ & DVRP & $\mathrm{ds}$ \\
\hline$V R P_{\text {Swiss }}$ & 0.712 & & & \\
\hline DVRP & 0.455 & -0.301 & & \\
\hline $\mathrm{ds}$ & -0.075 & 0.148 & -0.290 & \\
\hline FX & -0.074 & 0.154 & -0.296 & 0.999 \\
\hline
\end{tabular}

This table reports monthly correlations of variance risk premia (VRP), variance risk premium differential (DVRP), changes of spot exchange rate (ds), and excess foreign exchange return (FX) between the US and the UK, Japan, Europe, and Switzerland 
Table 4: Monthly VRP Differential and Excess Foreign Exchange Returns

\begin{tabular}{|c|c|c|c|c|c|c|c|c|c|c|}
\hline & GBP/USD & JPY/USD & EUR/USD & $\mathrm{CHF} / \mathrm{USD}$ & JPY/GBP & EUR/GBP & $\mathrm{CHF} / \mathrm{GBP}$ & EUR/JPY & CHF/JPY & CHF/EUR \\
\hline $\begin{array}{l}\beta_{D I R} \\
\text { t-stat }\end{array}$ & $\begin{array}{c}0.53 \\
(0.22)\end{array}$ & $\begin{array}{c}-2.83 \\
(-2.36)\end{array}$ & $\begin{array}{l}-1.52 \\
(-0.64)\end{array}$ & $\begin{array}{c}-2.64 \\
(-1.29)\end{array}$ & $\begin{array}{c}-0.30 \\
(-0.16)\end{array}$ & $\begin{array}{c}-0.71 \\
(-0.32)\end{array}$ & $\begin{array}{l}-2.10 \\
(-1.10)\end{array}$ & $\begin{array}{c}-1.14 \\
(-0.32)\end{array}$ & $\begin{array}{l}-1.40 \\
(-0.42)\end{array}$ & $\begin{array}{c}-5.89 \\
(-2.01)\end{array}$ \\
\hline Adj. $R^{2}$ & -0.68 & 2.20 & -0.41 & 0.08 & -0.70 & -0.67 & -0.11 & -0.60 & -0.60 & 1.87 \\
\hline $\begin{array}{l}\beta_{D I R} \\
\text { t-stat }\end{array}$ & $\begin{array}{c}0.13 \\
(0.06)\end{array}$ & $\begin{array}{l}-2.80 \\
(-2.35)\end{array}$ & $\begin{array}{l}-2.02 \\
(-0.86)\end{array}$ & $\begin{array}{l}-2.49 \\
(-1.13)\end{array}$ & $\begin{array}{l}-0.06 \\
(-0.03)\end{array}$ & $\begin{array}{c}0.21 \\
(0.11)\end{array}$ & $\begin{array}{l}-2.21 \\
(-1.12)\end{array}$ & $\begin{array}{l}-1.21 \\
(-0.34)\end{array}$ & $\begin{array}{l}-1.35 \\
(-0.40)\end{array}$ & $\begin{array}{l}-3.36 \\
(-1.15)\end{array}$ \\
\hline $\begin{array}{c}\gamma_{D V R P} \\
\text { t-stat }\end{array}$ & $\begin{array}{c}5.26 \\
(3.58)\end{array}$ & $\begin{array}{l}-0.29 \\
(-0.32)\end{array}$ & $\begin{array}{c}0.90 \\
(0.65)\end{array}$ & $\begin{array}{c}0.51 \\
(0.30)\end{array}$ & $\begin{array}{l}-2.40 \\
(-1.44)\end{array}$ & $\begin{array}{l}-2.67 \\
(-1.58)\end{array}$ & $\begin{array}{l}-4.16 \\
(-1.43)\end{array}$ & $\begin{array}{l}-0.79 \\
(-0.71)\end{array}$ & $\begin{array}{c}0.44 \\
(0.36)\end{array}$ & $\begin{array}{l}-2.06 \\
(-2.26)\end{array}$ \\
\hline Adj. $R^{2}$ & 9.98 & 1.61 & -0.61 & -0.47 & 2.14 & 2.97 & 6.94 & -0.77 & -1.16 & 8.22 \\
\hline
\end{tabular}

Monthly excess foreign exchange returns, $r x_{t+1}^{f x}$, and tests of explanation power of the interest rate differentials, $D I R_{t}$, and the variance risk premium differentials, $D V R P_{t}$. Monthly excess foreign exchange returns are calculated as returns on buying a forward contract on GBP/US, JPY/USD, EUR/USD, CHF/USD, JPY/GBP, EUR/GBP, CHF/GBP, EUR/JPY, CHF/JPY, and CHF/EUR and selling it in the spot rates after one period from January 2000 to October 2011. I report the slope coefficient $(\beta),(\gamma)$ and adjusted $R^{2}$ of the following regression;

$$
r x_{t}^{f x}=\alpha+\beta \times D I R_{t}+\gamma \times D V R P_{t}+\varepsilon_{t}
$$

Robust t-statistics following Newey and West (1987) with optimal number of lags according to Andrews (1991) are reported in parentheses. 
Table 5: Monthly Global VRP, Country-Specific VRP Differential, and Excess Foreign Exchange Return

\begin{tabular}{|c|c|c|c|c|c|c|c|c|c|c|}
\hline & GBP/USD & JPY/USD & EUR/USD & CHF/USD & JPY/GBP & EUR/GBP & $\mathrm{CHF} / \mathrm{GBP}$ & EUR/JPY & CHF/JPY & CHF/EUR \\
\hline$\beta_{D I R}$ & $\begin{array}{c}-0.44 \\
(-0.21)\end{array}$ & $\begin{array}{l}-3.30 \\
(-2.86)\end{array}$ & $\begin{array}{c}-1.88 \\
(-0.79)\end{array}$ & $\begin{array}{c}-2.13 \\
(-0.84)\end{array}$ & $\begin{array}{c}-1.69 \\
(-0.93)\end{array}$ & $\begin{array}{c}-0.50 \\
(-0.22)\end{array}$ & $\begin{array}{l}-2.58 \\
(-1.17)\end{array}$ & $\begin{array}{c}-2.77 \\
(-0.86)\end{array}$ & $\begin{array}{l}-2.81 \\
(-0.85)\end{array}$ & $\begin{array}{c}-2.67 \\
(-0.74)\end{array}$ \\
\hline$\gamma_{V R P D^{s}}$ & $\begin{array}{c}5.14 \\
(3.93)\end{array}$ & $\begin{array}{c}-0.01 \\
(-0.01)\end{array}$ & $\begin{array}{c}0.79 \\
(0.61)\end{array}$ & $\begin{array}{c}0.26 \\
(0.61)\end{array}$ & $\begin{array}{l}-1.56 \\
(-1.01)\end{array}$ & $\begin{array}{c}-2.47 \\
(-2.02)\end{array}$ & $\begin{array}{c}-3.92 \\
(-1.40)\end{array}$ & $\begin{array}{c}-0.53 \\
(-0.47)\end{array}$ & $\begin{array}{c}0.52 \\
(0.48)\end{array}$ & $\begin{array}{c}-2.16 \\
(-2.39)\end{array}$ \\
\hline$\delta_{G V R P}$ & $\begin{array}{c}2.45 \\
(5.41)\end{array}$ & $\begin{array}{c}-1.62 \\
(-2.81)\end{array}$ & $\begin{array}{c}1.06 \\
(0.93)\end{array}$ & $\begin{array}{c}1.24 \\
(1.03)\end{array}$ & $\begin{array}{l}-3.96 \\
(-4.41)\end{array}$ & $\begin{array}{c}-1.38 \\
(-1.58)\end{array}$ & $\begin{array}{l}-1.30 \\
(-1.31)\end{array}$ & $\begin{array}{c}2.62 \\
(2.34)\end{array}$ & $\begin{array}{c}2.78 \\
(2.58)\end{array}$ & $\begin{array}{c}0.16 \\
(0.25)\end{array}$ \\
\hline Adj. $R^{2}$ & 16.59 & 3.61 & -0.46 & -0.12 & 9.40 & 4.34 & 6.64 & 2.58 & 3.87 & 7.94 \\
\hline
\end{tabular}

Monthly excess foreign exchange returns, $r x_{t+1}^{f x}$, and tests of explanation power of the interest rate differentials, $D I R_{t}$, the country-specific variance risk premium differentials, $V R P D_{t}^{s}\left(=V R P_{t}^{s}-V R P_{t}^{* s}\right)$, and the global VRP, $G V R P_{t}$. Monthly excess foreign exchange returns are calculated as returns on buying a forward contract on GBP/US, JPY/USD, EUR/USD, CHF/USD, JPY/GBP, EUR/GBP, CHF/GBP, EUR/JPY, CHF/JPY, and CHF/EUR and selling it in the spot rates after one period from January 2000 to October 2011. I report the slope coefficient $(\beta),(\gamma),(\delta)$ and adjusted $R^{2}$ of the following regression;

$$
r x_{t}^{f x}=\alpha+\beta \times D I R_{t}+\gamma \times D V R P_{t}^{s}+\delta \times G V R P_{t}+\varepsilon_{t}
$$

where, the global VRP is a market capitalization weighted average of the individual country variance risk premia,

$$
G V R P_{t}=\sum \omega^{i} V R P_{t}^{i},
$$

and country specific variance risk premium are the error terms $\left(V R P_{t}^{s}=\zeta_{t}\right)$ in the following regression:

$$
V R P_{t}=\lambda+\rho \times G V R P_{t}+\zeta_{t}
$$

and

$$
D V R P_{t}^{s}=V R P_{t}^{s}-V R P_{t}^{* s}
$$

Robust t-statistics following Newey and West (1987) with optimal number of lags according to Andrews (1991) are reported in parentheses. 
Table 6: Monthly Consumption Growth Volatility Differential, Variance Risk Premium Differential, and Excess Foreign Exchange Returns

\begin{tabular}{|c|c|c|c|c|c|c|c|c|c|c|}
\hline & GBP/USD & JPY/USD & EUR/USD & $\mathrm{CHF} / \mathrm{USD}$ & JPY/GBP & EUR/GBP & $\mathrm{CHF} / \mathrm{GBP}$ & EUR/JPY & $\mathrm{CHF} / \mathrm{JPY}$ & CHF/EUR \\
\hline $\begin{array}{l}\beta_{D I R} \\
\text { t-stat }\end{array}$ & $\begin{array}{c}0.09 \\
(0.04)\end{array}$ & $\begin{array}{l}-2.82 \\
(-2.35)\end{array}$ & $\begin{array}{c}-0.99 \\
(-0.40)\end{array}$ & $\begin{array}{l}-3.05 \\
(-1.20)\end{array}$ & $\begin{array}{c}2.04 \\
(0.77)\end{array}$ & $\begin{array}{c}1.33 \\
(0.65)\end{array}$ & $\begin{array}{l}-3.16 \\
(-1.59)\end{array}$ & $\begin{array}{l}-1.13 \\
(-0.27)\end{array}$ & $\begin{array}{c}3.76 \\
(0.74)\end{array}$ & $\begin{array}{l}-3.66 \\
(-1.08)\end{array}$ \\
\hline $\begin{array}{c}\gamma_{D V O L C}^{\prime} \\
\text { t-stat }\end{array}$ & $\begin{array}{c}0.00 \\
(0.05)\end{array}$ & $\begin{array}{l}-0.07 \\
(0.03)\end{array}$ & $\begin{array}{l}-0.20 \\
(-0.95)\end{array}$ & $\begin{array}{c}0.03 \\
(0.49)\end{array}$ & $\begin{array}{c}0.25 \\
(1.77)\end{array}$ & $\begin{array}{c}0.10 \\
(1.23)\end{array}$ & $\begin{array}{c}0.14 \\
(1.65)\end{array}$ & $\begin{array}{c}0.01 \\
(0.05)\end{array}$ & $\begin{array}{c}0.15 \\
(1.50)\end{array}$ & $\begin{array}{c}0.21 \\
(0.58)\end{array}$ \\
\hline $\begin{array}{c}\gamma_{D V R P} \\
\text { t-stat }\end{array}$ & $\begin{array}{c}5.26 \\
(3.55)\end{array}$ & $\begin{array}{l}-0.24 \\
(-0.27)\end{array}$ & $\begin{array}{c}0.88 \\
(0.64)\end{array}$ & $\begin{array}{c}0.32 \\
(0.16)\end{array}$ & $\begin{array}{l}-3.46 \\
(-1.30)\end{array}$ & $\begin{array}{l}-2.33 \\
(-1.60)\end{array}$ & $\begin{array}{l}-4.95 \\
(-1.55)\end{array}$ & $\begin{array}{l}-0.79 \\
(-0.70)\end{array}$ & $\begin{array}{c}0.31 \\
(0.26)\end{array}$ & $\begin{array}{l}-2.19 \\
(-2.45)\end{array}$ \\
\hline Adj. $R^{2}$ & 9.32 & 0.96 & -0.76 & -1.14 & 4.33 & 3.20 & 7.76 & -1.51 & 0.65 & 7.74 \\
\hline
\end{tabular}

Monthly excess foreign exchange returns, $r x_{t+1}^{f x}$, and tests of explanation power of the interest rate differentials, $D I R_{t}$, consumption growth volatility differential, $D V O L C_{t}$, and the variance risk premium differentials, $D V R P_{t}$. Monthly excess foreign exchange returns are calculated as returns on buying a forward contract on GBP/US, JPY/USD, EUR/USD, CHF/USD, JPY/GBP, EUR/GBP, CHF/GBP, EUR/JPY, CHF/JPY, and CHF/EUR and selling it in the spot rates after one period from January 2000 to October 2011. slope coefficient $(\beta),\left(\gamma^{\prime}\right),(\gamma)$ and adjusted $R^{2}$ of the following regression;

$$
r x_{t}^{f x}=\alpha+\beta \times D I R_{t}+\gamma^{\prime} \times D V O L C_{t}+\gamma \times D V R P_{t}+\varepsilon_{t}
$$

Robust t-statistics following Newey and West (1987) with optimal number of lags according to Andrews (1991) are reported in parentheses. 
Table 7: Monthly Global Consumption Growth Volatility, Country-specific Consumption Growth Volatility Differential, Global VRP, Country-specific VRP Differential, and Excess Foreign Exchange Return

\begin{tabular}{|c|c|c|c|c|c|c|c|c|c|c|}
\hline & GBP/USD & JPY/USD & EUR/USD & CHF/USD & JPY/GBP & EUR/GBP & $\mathrm{CHF} / \mathrm{GBP}$ & EUR/JPY & CHF/JPY & CHF/EUR \\
\hline$\beta_{D I R}$ & $\begin{array}{c}0.02 \\
(0.01)\end{array}$ & $\begin{array}{c}-2.52 \\
(-2.05)\end{array}$ & $\begin{array}{c}-0.02 \\
(-0.01)\end{array}$ & $\begin{array}{c}-2.34 \\
(-0.87)\end{array}$ & $\begin{array}{c}-0.85 \\
(-0.28)\end{array}$ & $\begin{array}{c}0.17 \\
(0.07)\end{array}$ & $\begin{array}{l}-4.10 \\
(-1.92)\end{array}$ & $\begin{array}{c}-4.07 \\
(-1.05)\end{array}$ & $\begin{array}{c}0.84 \\
(0.18)\end{array}$ & $\begin{array}{c}-6.21 \\
(-1.05)\end{array}$ \\
\hline$\gamma_{V O L C D^{s}}^{\prime}$ & $\begin{array}{c}0.03 \\
(0.19)\end{array}$ & $\begin{array}{c}0.09 \\
(0.46)\end{array}$ & $\begin{array}{c}-0.16 \\
(-0.74)\end{array}$ & $\begin{array}{c}0.05 \\
(0.73)\end{array}$ & $\begin{array}{c}0.11 \\
(0.46)\end{array}$ & $\begin{array}{c}0.06 \\
(0.50)\end{array}$ & $\begin{array}{c}0.13 \\
(1.59)\end{array}$ & $\begin{array}{c}-0.18 \\
(-0.61)\end{array}$ & $\begin{array}{c}0.09 \\
(1.03)\end{array}$ & $\begin{array}{c}0.05 \\
(0.86)\end{array}$ \\
\hline$\delta_{G V O L C}^{\prime}$ & $\begin{array}{c}0.09 \\
(0.41)\end{array}$ & $\begin{array}{c}0.52 \\
(2.05)\end{array}$ & $\begin{array}{c}0.42 \\
(1.37)\end{array}$ & $\begin{array}{c}0.22 \\
(0.73)\end{array}$ & $\begin{array}{c}0.50 \\
(1.70)\end{array}$ & $\begin{array}{c}0.19 \\
(0.85)\end{array}$ & $\begin{array}{c}0.24 \\
(1.04)\end{array}$ & $\begin{array}{c}-0.21 \\
(-0.60)\end{array}$ & $\begin{array}{l}-0.36 \\
(-1.14)\end{array}$ & $\begin{array}{c}0.16 \\
(0.92)\end{array}$ \\
\hline$\gamma_{V R P D^{s}}$ & $\begin{array}{c}5.20 \\
(3.93)\end{array}$ & $\begin{array}{c}0.12 \\
(0.14)\end{array}$ & $\begin{array}{c}0.88 \\
(0.68)\end{array}$ & $\begin{array}{c}0.19 \\
(0.09)\end{array}$ & $\begin{array}{l}-1.30 \\
(-0.87)\end{array}$ & $\begin{array}{c}-2.34 \\
(-1.79)\end{array}$ & $\begin{array}{l}-4.56 \\
(-1.50)\end{array}$ & $\begin{array}{c}-0.53 \\
(-0.45)\end{array}$ & $\begin{array}{c}0.47 \\
(0.42)\end{array}$ & $\begin{array}{l}-2.38 \\
(-2.51)\end{array}$ \\
\hline$\delta_{G V R P}$ & $\begin{array}{c}2.46 \\
(5.41)\end{array}$ & $\begin{array}{c}-1.42 \\
(-2.31)\end{array}$ & $\begin{array}{c}1.19 \\
(1.03)\end{array}$ & $\begin{array}{c}1.22 \\
(0.96)\end{array}$ & $\begin{array}{c}-3.73 \\
(-4.55)\end{array}$ & $\begin{array}{c}-1.30 \\
(-1.50)\end{array}$ & $\begin{array}{c}-1.54 \\
(-1.51)\end{array}$ & $\begin{array}{c}2.65 \\
(2.30)\end{array}$ & $\begin{array}{c}2.42 \\
(2.14)\end{array}$ & $\begin{array}{c}-0.01 \\
(-0.01)\end{array}$ \\
\hline Adj. $R^{2}$ & 15.47 & 4.76 & -0.67 & -0.79 & 10.01 & 3.62 & 7.29 & 1.94 & 3.68 & 7.42 \\
\hline
\end{tabular}

Monthly excess foreign exchange returns, $r x_{t+1}^{f x}$, and tests of explanation power of the interest rate differentials, $D I R_{t}$, the country-specific consumption growth volatility differentials, $V O L C D^{s}\left(=V O L C_{t}^{s}-V O L C_{t}^{* s}\right)$, and the global consumption growth volatility, $G V O L C_{t}$, the country-specific variance risk premium differentials, $V R P D^{s}$, and the global VRP, $G V R P_{t}$. Monthly excess foreign exchange returns are calculated as returns on buying a forward contract on GBP/US, JPY/USD, EUR/USD, CHF/USD, JPY/GBP, EUR/GBP, CHF/GBP, EUR/JPY, CHF/JPY, and CHF/EUR and selling it in the spot rates after one period from January 2000 to October 2011. I report the slope coefficient $(\beta),\left(\gamma^{\prime}\right),\left(\delta^{\prime}\right),(\gamma),(\delta)$ and $R^{2}$ of the following regression;

$$
r x_{t}^{f x}=\alpha+\beta \times D I R_{t}+\gamma^{\prime} \times D V O L C_{t}^{s}+\delta^{\prime} \times G V O L C_{t}+\varepsilon_{t}+\gamma \times D V R P_{t}^{s}+\delta \times G V R P_{t}+\varepsilon_{t}
$$

where, the global consumption growth volatility is a market capitalization weighted average of the individual country consumption growth volatility,

$$
G V O L C_{t}=\sum \omega^{i} V O L C_{t}^{i}
$$

and country specific consumption growth volatility are the error terms $\left(V O L C_{t}^{s}=\zeta_{t}^{\prime}\right)$ in the following regression:

$$
V O L C_{t}=\lambda^{\prime}+\rho^{\prime} \times G V O L C_{t}+\zeta_{t}^{\prime}
$$

and

$$
D V O L C_{t}^{s}=V O L C_{t}^{s}-V O L C_{t}^{* s}
$$

Robust t-statistics following Newey and West (1987) with optimal number of lags according to Andrews (1991) are reported in parentheses. 
Table 8: Monthly Contemporaneous Comovements between Cross-country Excess Equity Return and Excess Foreign Exchange Return

\begin{tabular}{|c|c|c|c|c|c|c|c|c|c|c|}
\hline & GBP/USD & JPY/USD & EUR/USD & $\mathrm{CHF} / \mathrm{USD}$ & JPY/GBP & EUR/GBP & $\mathrm{CHF} / \mathrm{GBP}$ & EUR/JPY & $\mathrm{CHF} / \mathrm{JPY}$ & $\mathrm{CHF} / \mathrm{EUR}$ \\
\hline $\begin{array}{c}\alpha \\
\text { t-stat }\end{array}$ & $\begin{array}{c}0.00 \\
(0.21)\end{array}$ & $\begin{array}{c}-0.00 \\
(-0.12)\end{array}$ & $\begin{array}{c}0.00 \\
(0.65)\end{array}$ & $\begin{array}{c}0.00 \\
(1.48)\end{array}$ & $\begin{array}{c}-0.00 \\
(-0.39)\end{array}$ & $\begin{array}{c}0.00 \\
(0.67\end{array}$ & $\begin{array}{c}0.00 \\
(1.40)\end{array}$ & $\begin{array}{c}0.00 \\
(0.76)\end{array}$ & $\begin{array}{c}0.00 \\
(1.61)\end{array}$ & $\begin{array}{c}0.00 \\
(0.42)\end{array}$ \\
\hline $\begin{array}{c}\beta_{d \pi} \\
\text { t-stat }\end{array}$ & $\begin{array}{c}0.48 \\
(5.05)\end{array}$ & $\begin{array}{c}0.17 \\
(2.65)\end{array}$ & $\begin{array}{c}0.26 \\
(3.42)\end{array}$ & $\begin{array}{c}0.46 \\
(4.41)\end{array}$ & $\begin{array}{c}0.23 \\
(2.46)\end{array}$ & $\begin{array}{c}0.21 \\
(2.48)\end{array}$ & $\begin{array}{c}0.42 \\
(2.86)\end{array}$ & $\begin{array}{c}0.08 \\
(1.07)\end{array}$ & $\begin{array}{c}0.21 \\
(2.68)\end{array}$ & $\begin{array}{c}-0.05 \\
(-0.86)\end{array}$ \\
\hline Adj. $R^{2}$ & 16.83 & 7.18 & 5.19 & 18.83 & 7.90 & 4.51 & 14.94 & 0.39 & 9.18 & 0.24 \\
\hline
\end{tabular}

$\bullet \quad$ Monthly excess foreign exchange returns, $r x_{t+1}^{f x}$, and tests of explanation power of equity premium differentials, $d \pi_{r, t}$, which is equity premium in domestic country, $\pi_{r, t}$, minus equity premium in the foreign country, $\pi_{r, t}{ }^{*}$. Monthly excess foreign exchange returns are calculated as returns on buying a forward contract on GBP/US, JPY/USD, EUR/USD, CHF/USD, JPY/GBP, EUR/GBP, CHF/GBP, EUR/JPY, CHF/JPY, and CHF/EUR and selling it in the spot rate after one period from January 2000 to October 2011. Equity premium differentials are calculated based on differences between excess return of aggregated stock indices, including S\&P 500, FTSE 100, Nikkei 225, STOXX, and SWX. I report constant $(\alpha)$, the slope coefficient $(\beta)$, and adjusted $R^{2}$ of the following regression;

$$
r x_{t}^{f x}=\alpha+\beta \times d \pi_{r, t}+\varepsilon_{t}
$$

where,

$$
d \pi_{r, t}=\pi_{r, t}-\pi_{r, t}{ }^{*}
$$

and

$$
r x_{t}^{f x}=\frac{1}{2} \operatorname{var}\left[m_{t+1}\right]-\frac{1}{2} \operatorname{var}\left[m_{t+1}^{*}\right] \equiv \frac{1}{2} \pi_{r, t}-\frac{1}{2} \pi_{r, t}^{*}=\frac{1}{2} d \pi_{r, t}
$$

Robust t-statistics following Newey and West (1987) with optimal number of lags according to Andrews (1991) are reported in parentheses. 
Table 9: Monthly Global VRP, Country-specific VRP Differential, and Cross-country Excess Equity Return Differential

\begin{tabular}{ccccccccccc}
\hline \hline & & & & & & & & & & \\
& US-UK & US-JP & US-EU & US-CH & UK-JP & UK-EU & UK-CH & JP-EU & JP-CH & EU-CH \\
\hline \multirow{2}{*}{$\gamma_{V R P D^{s}}$} & 2.65 & 1.29 & -0.31 & 2.44 & 0.16 & -0.34 & -0.71 & 1.51 & 1.31 & 0.99 \\
& $(2.41)$ & $(0.94)$ & $(-0.38)$ & $(1.39)$ & $(0.10)$ & $(-0.24)$ & $(-0.35)$ & $(0.85)$ & $(0.90)$ & $(0.84)$ \\
$\delta_{G V R P}$ & 2.64 & 3.08 & 1.87 & 2.63 & 0.44 & -0.78 & -0.01 & -1.21 & -0.45 & 0.76 \\
& $(5.11)$ & $(2.78)$ & $(2.28)$ & $(2.00)$ & $(0.34)$ & $(-0.93)$ & $(-0.02)$ & $(-0.82)$ & $(-0.32)$ & $(1.05)$ \\
\multirow{2}{*}{ Adj. $R^{2}$} & 14.18 & 3.20 & 2.22 & 8.73 & -1.36 & -0.66 & -1.21 & 0.10 & -0.69 & -0.45 \\
\hline \hline
\end{tabular}

Monthly cross-country excess equity return differential, $d \pi_{r, t}\left(=\pi_{r, t}-\pi_{r, t}{ }^{*}\right)$, and tests of explanation power of the country-specific variance risk premium differentials, $V R P D_{t}^{s}$, and the global VRP, $G V R P_{t}$. Monthly equity premium differentials are calculated based on differences between excess return of aggregated stock indices, including S\&P 500 (US), FTSE 100 (UK), Nikkei 225 (JP), STOXX (EU), and SWX $(\mathrm{CH})$ from January 2000 to October 2011. I report the slope coefficients, $(\gamma)$ and $(\delta)$, and adjusted $R^{2}$ of the following regression;

$$
d \pi_{r, t}=\alpha+\gamma \times D V R P_{t}^{s}+\delta \times G V R P_{t}+\varepsilon_{t}
$$

Robust t-statistics following Newey and West (1987) with optimal number of lags according to Andrews (1991) are reported in parentheses. 
Table 10: Excess Interbank-Rate Returns

\begin{tabular}{cccccc}
\hline \hline & & & & & \\
& US & UK & Japan & Europe & Swiss \\
\hline$\beta_{F S}^{\prime}$ & 0.56 & 0.76 & 0.41 & 0.82 & 0.53 \\
& $(2.82)$ & $(3.97)$ & $(2.64)$ & $(4.30)$ & $(4.82)$ \\
Adj. $R^{2}$ & 13.21 & 22.33 & 19.76 & 29.98 & 10.71 \\
\hline$\beta_{F S}^{\prime}$ & 0.58 & 0.88 & 0.39 & 0.81 & 0.65 \\
& $(2.17)$ & $(3.98)$ & $(2.96)$ & $(4.19)$ & $(4.55)$ \\
$\gamma^{\prime}{ }_{V R P}$ & -3.10 & -4.80 & 0.37 & -0.68 & -3.52 \\
& $(-2.91)$ & $(-2.34)$ & $(1.95)$ & $(-0.57)$ & $(-1.64)$ \\
Adj. $R^{2}$ & 27.40 & 45.46 & 21.91 & 30.62 & 31.79 \\
\hline \multirow{2}{*}{${ }^{\prime}{ }_{F S}$} & 0.52 & 0.88 & 0.48 & 0.88 & 0.42 \\
t-stat & $(2.89)$ & $(4.62)$ & $(3.52)$ & $(4.15)$ & $(2.91)$ \\
$\gamma^{\prime}{ }_{V R P}$ & -5.34 & 10.83 & 0.34 & 3.28 & 0.19 \\
t-stat & $(-1.93)$ & $(-2.11)$ & $(1.46)$ & $(1.79)$ & $(0.17)$ \\
$\delta_{G V R P}^{\prime}$ & -2.85 & -4.67 & 0.24 & -1.66 & -4.15 \\
t-stat & $(-2.59)$ & $(-2.42)$ & $(0.99)$ & $(-1.66)$ & $(-2.06)$ \\
Adj. $R^{2}$ & 28.19 & 47.10 & 25.77 & 39.97 & 37.43 \\
\hline \hline
\end{tabular}

Annualized 1 month excess holding period returns are: $b p r_{t, 2}^{i b}=y_{t-1,2}-y_{t, 1}-y_{t-1,1}$, where, $y_{t, n}(n \in\{1,2\})$ is the interbank return in the US, UK, Japan, Europe, and Switzerland with n-month to maturity at time $t$ from January 2000 to October 2011. The lagged forward spread is equal to:

$$
f s_{t-1}^{i b}(1,2)=y_{t-1,2}-y_{t-1,1}
$$

where, $f s_{t-1}^{i b}(1,2)$ is forward spread of a contract for 2-month ahead with 1-month length.

The excess bond returns $\left(b p r_{t+1, n}^{i b}\right)$ and tests of explanation power of lagged forward spread $\left(f s_{t-1}^{i b}-y_{t-1,2}\right)$, variance risk premium $\left(V R P_{t}\right)$, and global variance risk premium $\left(G V R P_{t}\right)$. I report the constant, slope coefficient $(\beta),(\gamma)$, and adjusted $\left(R^{2}\right)$ of the following regression:

$$
b p r_{t, 2}^{i b}=\alpha^{\prime}+\beta^{\prime} \times\left(f s_{t-1}^{i b}(1,2)-y_{t-1,2}\right)+\gamma^{\prime} \times V R P_{t}^{s}+\delta^{\prime} \times G V R P_{t}+\varepsilon^{\prime}
$$

Robust t-statistics following Newey and West (1987) with optimal number of lags according to Andrews (1991) are reported in parentheses. 
Table 11: Monthly Out-of-Sample $R^{2}$

\begin{tabular}{ccccccccccc}
\hline \hline & GBP/USD & JPY/USD & EUR/USD & CHF/USD & JPY/GBP & EUR/GBP & CHF/GBP & EUR/JPY & CHF/JPY & CHF/EUR \\
\hline$R_{\text {OOS }}^{2}$ & 19.71 & -5.40 & -14.15 & -6.75 & 6.98 & 4.79 & 0.78 & 0.43 & 2.65 & 3.69 \\
\hline \hline
\end{tabular}

Considering the following regression:

$$
r_{t+1}^{F X}=\alpha+\gamma D V R P_{t}^{s}+\delta G V R P_{t}+\varepsilon_{t}
$$

the monthly $R^{2}$ Out-of-Sample, $R_{O O S}^{2}$, is calculated similar to Goyal and Welch (2008). This means,

$$
R_{O O S}^{2}=1-\frac{M S E_{D V R P}}{M S E_{H M}},
$$

where,

$$
\begin{aligned}
M S E_{D V R P} & =\frac{1}{T-s_{0}} \sum\left(r_{t+1}^{F X}-\hat{r}_{t}^{D V R P}\right)^{2} \\
M S E_{H M} & =\frac{1}{T-s_{0}} \sum\left(r_{t+1}^{F X}-\bar{r}_{t}^{H M}\right)^{2}
\end{aligned}
$$

$M S E_{D V R P}$ is the mean squared error of the out-of-sample prediction using the country specific VRP differential and the global VRP, $M S E_{H M}$ is the mean squared error of the historical sample mean, $r_{t+1}^{F X}$ is the monthly excess exchange return, $\hat{r}_{t}^{D V R P}$ is out-of-sample estimation of the monthly excess exchange return using the DVRP and the common $\operatorname{VRP}\left(\hat{r}_{t}^{D V R P}=\hat{\alpha}+\hat{\gamma} D V R P_{t}^{s}+\hat{\delta} G V R P_{t}\right)$, and $\bar{r}_{t}^{H M}$ is historical mean of monthly excess exchange return. I use the related data for GBP/US, JPY/USD, EUR/USD, CHF/USD, JPY/GBP, EUR/GBP, CHF/GBP, EUR/JPY, CHF/JPY, and CHF/EUR from January 2000 to December 2004 (5 years) as my initial sample. Then, I calculate the $R_{O O S}^{2}$ from October 2000 to October 2011. Note: A positive (negative) $R_{O O S}^{2}$ means the monthly DVRP predicts monthly excess foreign exchange better (worst) than the historical mean. 